\title{
Cohort Fertility, Parity Progression, and Family Size in Former Yugoslav Countries
}

\author{
Ivan Čipin, Kryštof Zeman, Petra Međimurec
}

\begin{abstract}
Yugoslavia was a union of countries at the crossroads of cultures, rich in diversity, bringing together heterogeneous populations with very different demographic transition pathways, particularly with respect to fertility. This paper studies the trends and patterns of cohort fertility in former Yugoslav countries, similarities and differences between the countries, and their possible clustering. Do former Yugoslav countries exhibit persistent diversity to this day, or is there convergence in terms of cohort fertility behaviour? If so, what might account for this homogeneity within Yugoslavia's heterogeneity? We trace how fertility behaviour changed from the turn of the twentieth century, when Yugoslav countries began their progression from agrarian into industrial capitalist societies. We consider the factors related to a rapid transformation to socialist modernity after 1945 and proceed to investigate the federation's breakup and the successor states' transitions to market economies in the early 1990s. Our study thus covers a century of socioeconomic and fertility developments within the region. We analyse census data on children born by means of the completed cohort fertility rate, parity progression ratios, and parity composition. Our results show that while fertility levels decreased in all former Yugoslav republics, this happened at different speeds and taking different paths. Parity progression to higher birth orders was particularly responsible for this development, as well as for the differences and similarities between the respective republics. Former Yugoslav republics are clustered into three groups, where Croatia, Slovenia, and Serbia form the low fertility group, and Bosnia-Herzegovina, North Macedonia, and Montenegro belong to a higher fertility group. Kosovo remains a special case with exceptionally high fertility in the European context. We conclude that this clustering stems from a complex interplay of historical, political, economic and social factors.
\end{abstract}

Keywords: Cohort fertility · Census data · Former Yugoslav countries · Parity progression ratios $\cdot$ Parity composition 


\section{Introduction}

The year 2018 marked the centennial of the birth of Yugoslavia, a former state in south-eastern Europe, about the size of the United Kingdom and with a population of more than 12 million at the time of its creation (Simeunović 1964). From a demographic perspective, Yugoslavia is an interesting case to explore, with its staggeringly diverse collection of ethnicities that were long ruled by two major foreign empires. The downfall of the Austro-Hungarian and Ottoman empires by the end of World War I made grounds for the realisation of the idea of a unified South Slavic state. The so-called First Yugos/avia was founded as a state union of Serbs, Croats, and Slovenes, but in reality, it was a multinational kingdom with about two million members of ethnic minorities (Erlich 1966). After the turbulent times of World War II, the rebirth of the country was realised in 1945 as a socialist federal republic. It comprised six socialist republics: Bosnia-Herzegovina, Croatia, Macedonia, Montenegro, Serbia, and Slovenia, as well as two autonomous provinces within Serbia (Kosovo and Vojvodina). In the 1990s, Yugoslavia broke up in a series of wars that ultimately ended with the establishment of seven sovereign states: Bosnia-Herzegovina, Croatia, Kosovo, North Macedonia, Montenegro, Serbia, and Slovenia.

Yugoslavia was very rich in socio-economic and cultural diversity. This stemmed from a complex interplay between historical, political, economic, and social factors. Western influences (mostly originating from the Austro-Hungarian era) in some parts of the country collided with Ottoman influences in others. Yugoslavia was at the crossroads of cultures, bringing together heterogeneous populations with significantly different demographic transition pathways, especially with respect to fertility. The cultural setting was multifaceted, encompassing a mix of religious identities (Orthodox Christians, Roman Catholics, and Muslims), with strikingly different norms, values, and family practices.

Given Yugoslavia's multinational character, such a complex economic, cultural, and institutional setting may have produced different effects on cohort fertility outcomes in each of the former constituent states. Some parts of Yugoslavia experienced a much earlier onset of the fertility decline, while others maintained high fertility even after the post-World War II baby boom era (Breznik 1991). Fertility trends in Yugoslav regions were a mirror image of global fertility trends: Differences between the most and least developed parts of Yugoslavia reflected worldwide differences in fertility levels between high-income and least-developed countries.

Those unfamiliar with Yugoslavia's background could easily assume that its constituent states exhibited similar demographic patterns. However, as the story unfolds, it becomes increasingly difficult to imagine that Slovenia and Kosovo were part of the same country. Historically, for example, Kosovo strongly lagged behind Slovenia in its economic and overall social development. Infant mortality declined below the threshold of 100 infant deaths per 1000 births soon after World War II in Slovenia and Montenegro, but this decline did not occur in Bosnia, Macedonia, and Kosovo until the 1960s (Simeunović 1964). In the 1980s, the gross social product per capita of Slovenia was seven times higher than that of the least developed region within Yugoslavia, Kosovo (Gligorov 2016). 
Tab. 1: $\quad$ Crude birth rate (1900-1939) and total fertility rate (1950-2018)

\begin{tabular}{lrrrrrrr}
\hline Period & $\begin{array}{c}\text { Bosnia- } \\
\text { Herzegovina }\end{array}$ & Croatia & $\begin{array}{c}\text { North } \\
\text { Macedonia }\end{array}$ & Montenegro & Serbia & Slovenia & Kosovo \\
\hline $\begin{array}{l}\text { Crude birth rate } \\
\text { around 1900 }\end{array}$ & 41.0 & 38.2 & - & - & 38.0 & 34.0 & - \\
1931 & 40.3 & 31.4 & 37.6 & 30.9 & 35.1 & 27.3 & 37.5 \\
1939 & 35.1 & 24.1 & 32.8 & 28.6 & 22.6 & 21.7 & 31.5 \\
\hline Total fertility rate & & & & & & & \\
1950 & 5.22 & 2.91 & 5.81 & 4.32 & 3.17 & 2.98 & 7.03 \\
1960 & 3.91 & 2.18 & 4.11 & 3.47 & 2.09 & 2.17 & 6.70 \\
1970 & 2.67 & 1.81 & 2.99 & 2.61 & 1.86 & 2.11 & 5.48 \\
1980 & 1.88 & 1.91 & 2.45 & 2.16 & 1.85 & 2.12 & 4.83 \\
1990 & 1.71 & 1.63 & 2.06 & 1.79 & 1.75 & 1.46 & 3.58 \\
2000 & - & 1.42 & 1.88 & 1.85 & 1.43 & 1.26 & - \\
2010 & 1.63 & 1.55 & 1.56 & 1.66 & 1.40 & 1.58 & 2.46 \\
2018 & - & 1.47 & 1.42 & 1.76 & 1.49 & 1.60 & - \\
\hline
\end{tabular}

The value for Bosnia-Herzegovina, 2010, is our own estimate using 2013 census data.

The value for Kosovo, 2010, is estimated using 2011 census data, from the European Demographic Datasheet 2014 (WIC 2014).

Source: CBR: Rašević (1971) and Gelo (1987). Data for Serbia (1900-2000) are for Central Serbia only. TFR: Human Fertility Collection (2019), namely Observatoire Démographique Européen (ODE) (for 1950), Gaćeša 1991 (for 1960-1980), National Statistical Institutes (for 1990-2017); Eurostat (2019).

Yugo-specific fertility dynamics, however, have not yet been fully explored in the demographic literature (see Breznik 1991 for a more detailed review). Existing research mostly deals with the long-term change in period fertility (Rašević 1971; Breznik et al. 1972; Breznik 1980), but only partially - if at all - includes cohort fertility analyses. Cohort data on fertility rates, family size, and parity composition have rarely been studied for the region, with some notable exceptions. Rašević (1971) and Breznik and colleagues (1972) used 1961 census data to construct cohort fertility rates, parity progression ratios, and cohort-specific proportions of childless women. They also reported on basic demographic, socioeconomic, and regional cohort fertility differentials. Breznik (1991) did similar work with 1971 and 1981 census data. These studies are now dated and - more importantly - not available in English, which makes them mostly inaccessible to the international research community. A small number of English-language studies on fertility developments in the former Yugoslav countries are either part of a broader cross-European cohort fertility analyses (Frejka/Sardon 2006; Frejka/Gietel-Basten 2016) or refer to the most recent period fertility trends (Lerch 2018).

To the best of our knowledge, this study is the first to investigate historical cohort fertility trends and patterns that covers the full course of the fertility transitions in all seven Yugoslav successor states. In this paper, we aim to describe how cohort fertility evolved in the formerly Yugoslav countries, we look for country clusters 
that share similar characteristics and we try to assess whether a common Yugoslav background has spurred between-cluster convergence. More specifically, we address the following research questions:

1. What are the trends and patterns of cohort fertility in the former Yugoslav countries?

2. Are some countries more similar to one another than to others? Can country clusters be identified? And, if so, what might account for this homogeneity within Yugoslavia's heterogeneity?

3. Do former Yugoslav countries exhibit persistent (between-cluster) diversity, or is there (at least some) convergence in terms of cohort fertility behaviour?

Similarities and differences in fertility decline can be related to the socioeconomic and cultural contexts within each Yugoslav country. In this paper, we further aim to trace how fertility behaviour changed from the turn of the twentieth century, when Yugoslav countries began their progression from agrarian into industrial capitalist societies. Then, we consider the factors related to a rapid transformation to socialist modernity after 1945. Finally, we investigate the federation's breakup and the successor states' transitions to market economies in the early 1990s. Our study thus covers a century of socioeconomic and fertility developments within the region.

\section{Socioeconomic, cultural, and institutional contexts of fertility change}

Before turning to a more detailed investigation of the specific economic, social, and institutional contexts of fertility change in Yugoslavia, we provide a short overview of the main theoretical perspectives on the historical fertility transition. There is no consensus among demographers on the causes and mechanisms of fertility decline in Europe over the past two centuries. Dominant theories and explanations of why fertility declined often dichotomise "economy" versus "culture" (Balbo et al. 2013). In this paper, we present a macro-level study of fertility change and build on these two broad approaches in an attempt to explain cohort fertility dynamics in former Yugoslavia.

According to classical demographic transition theory (see Kirk 1996), economic factors are central to fertility decline. Numerous macro-level studies stress the role of modernisation, industrialisation, urbanisation, educational expansion, labour market changes, and finally yet importantly, infant mortality decline in adapting to new socioeconomic conditions resulting in family size reductions. Economists extended the scope of the original formulation of demographic transition theory. The most influential extension, the microeconomic theory of fertility (Becker 1960, 1991), applies the economic theory of consumer behaviour to fertility decisions and focuses on couples' reactions to changes in income and the costs of children. An especially popular contribution of the economic analysis of fertility is the well-known quantity-quality trade-off, with parents having fewer children (a drop in quantity), but at a higher cost (an increase in quality). The economic study of fertility was fur- 
ther extended by Easterlin's relative income hypothesis (Easterlin 1975), which links relative cohort size to income potential and fertility, with fertility cycles and baby booms and busts as results. In his intergenerational wealth flow theory, Caldwell (1976) offered a hypothesis according to which in traditional societies, children work and contribute to family income, while in modern societies, children become far more costly to their parents, so the net wealth flow reverses.

The largest empirical test of the demographic transition theory, the European Fertility Project directed by Ansley Coale (Coale/Watkins 1986), brought about new evidence suggesting that the fertility transition was driven more strongly by cultural than socioeconomic factors. The so-called "innovation diffusion" perspective hypothesises that fertility declined because new knowledge about birth control spread alongside more permissive values and attitudes that made birth control more socially acceptable (Cleland/Wilson 1987). Starting from the 1960s, in Western and Northern Europe, this perspective on fertility decline gave rise to a novel narrative of the diffusion of new family and fertility behaviour: the theory of the second demographic transition (van de Kaa 1987; Leasthaeghe 1995). The basic premise of the theory is that ideational shifts led to profound demographic and social changes, including declining marriage rates, rising ages at first marriage, increasing cohabitation, rising divorce rates, increasing nonmarital fertility, postponement of childbearing, below-replacement fertility, rising childlessness among women ever in a union, rising symmetry in gender roles, efficient contraception use, the sexual revolution, rising female education levels, greater female economic autonomy, the retreat of the state, increasing refusal of authority, individual autonomy, and self-realisation. The creators of this theory acknowledged the contribution of economic and structural changes to this cultural shift, but it is the ideational change that lies at the heart of the explanation (Surkyn/Lesthaeghe 2004).

During the period covered by our study, which stretches over more than a century (from 1890s to early 2010s), numerous factors shaped fertility change in the former Yugoslav countries. Although the constituent states held together for more than 70 years, the contexts within which fertility changes took place were diverse. This study does not aim to provide an exhaustive examination of all possible factors that could have shaped the reproductive behaviour of the population of Yugoslavia. We only want to point to the most relevant factors that are most likely to have triggered and patterned completed fertility. We start with a brief timeline of the rise and fall of Yugoslavia, followed by a description of key domains related to fertility reduction: economic development; family life; women's education and economic activity; fertility regulation; and population policy.

\subsection{The rise and fall of Yugoslavia}

In the territory that was known as Yugoslavia for much of the twentieth century, today we find seven independent states. However, not all of them were independent before the first unification at the end of World War I. Serbia and Montenegro were independent kingdoms at the turn of the century, and previously vassals of the Ottoman Empire. Ethnically mixed Bosnia-Herzegovina and Macedonia remained under 
Ottoman rule and cultural influence even longer, until 1878 and 1912, respectively. Croatia and Slovenia were part of the Austro-Hungarian Empire until its dissolution in 1918 (Calic 2019).

Among all states established in Europe after World War I, Yugoslavia was the most diverse and complex (Calic 2019). The narrative of Yugoslavia starts in 1918, when the South Slavs united under the state that had been organised as a monarchy, formally named "Kingdom of the Serbs, Croats and Slovenes" and ruled by the Serbian Karađorđević dynasty. The state changed its name to "Kingdom of Yugoslavia" in 1929 as other nations and groups such as Macedonians, Bosniak Muslims, Montenegrins, and many other ethnic minorities lived under the heading of the same state name. The first Yugoslavia ceased to exist when World War II broke out in the region in 1941. After the war ended in 1945, Yugoslavia was renewed as a Federal People's Republic of Yugoslavia, with the central aims of internal cohesion, socialist/communist brotherhood, and unity. In 1963, the country's name was officially changed to the Socialist Federal Republic of Yugoslavia (Calic 2019). Yugoslavia fell apart in a series of wars in Slovenia (1991), Croatia (1991-1995), Bosnia-Herzegovina (19921995) and Kosovo (1998-1999), with tens of thousands dead, as well as millions of refugees and displaced persons. The dissolution of socialist Yugoslavia began in 1991, when Slovenia and Croatia declared their independence, followed by Macedonia and Bosnia-Herzegovina. In 1992, Serbia (including Kosovo and Vojvodina) and Montenegro established a rump state: the Federal Republic of Yugoslavia. In 2003, Serbia and Montenegro established a short-lived state union - dropping the name "Yugoslavia" - that lasted until 2006, when Montenegro declared its independence. Finally, in 2008, Kosovo declared independence from Serbia, which signified the final breakup of Yugoslavia.

\subsection{Sharp contrasts in economic development}

In the late nineteenth century, virtually all parts of what would become Yugoslavia were economically underdeveloped relative to the rest of Europe and predominantly agrarian. Even in the most developed region, Slovenia, the significant majority of the population were peasants, and three-quarters of the economically active population worked in agriculture (Rašević 1971). In the interwar period, Yugoslavia had the highest percentage of agrarian population in Europe (Erlich 1966). Socioeconomic factors prompted differing demographic patterns: Slovenia roughly resembled Western Europe with its relatively low fertility, while Kosovo had a high pretransitional fertility (Breznik et al. 1972). Somewhat stronger industrial development had occurred in Slovenia and Croatia, which had been part of the Austro-Hungarian Empire. The beginning of fertility decline coincides with the development of capitalism. In Croatia, industrial development progressed in the first decade of the twentieth century, but agriculture was still the predominant economic activity. At the same time, the emergence of capitalism in the late nineteenth and early twentieth centuries in Serbia not only resulted in economic changes, but also in broader societal ones (the development of cities, greater social mobility, the spread of literacy). These processes, although slow, influenced fertility through new views on family 
size, age at marriage, and marriage formation and dissolution (Rašević 1971). Other Yugoslav republics were among the last in Europe to experience modernisation (Leasure 1992): Economic and industrial development in early twentieth-century Bosnia-Herzegovina, Macedonia, and Montenegro was very slow and late to start, delaying socioeconomic change affecting the reproductive behaviour. In Kosovo, high fertility before World War II resulted from what remained of the feudal system. Extensive agriculture demanded labour force, a demand further heightened by high levels of child and adult mortality (Rašević 1971).

The gap between population growth and economic growth brought about agrarian overpopulation and unemployment (Calic 2019). Agrarian overpopulation and unemployment occurred because the economy was developing slowly and not creating enough jobs, which spurred the great waves of emigration from Slovenia and Croatia (Rašević 1971; Gelo 1987). In Slovenia, and to a lesser extent, in Croatia, high rates of unmarried women in the late nineteenth and early twentieth centuries at least in part resulted from gender imbalances caused by the higher emigration rates of young, unmarried males (Rašević 1971). ${ }^{1}$

Throughout the interwar years, the agrarian character of the Yugoslav economy continued to dominate, and the country remained largely undeveloped. The vast majority of the population worked in agriculture, the share of the urban population grew slowly, and literacy was slow to expand, but there was far less emigration than in the previous decades (Rašević 1971). There was a speed-up in industrialisation throughout the 1920s, but Yugoslavia had not yet developed the typical features of a modern society (Calic 2019). The impact of the great economic crisis on fertility and family dynamics was greater in Slovenia, Croatia, and Serbia due to a stronger penetration of capitalism. Bosnia-Herzegovina, Macedonia, Montenegro, and Kosovo were underdeveloped agrarian communities with rigid social norms regarding reproduction, and were therefore relatively isolated from global economic trends at the time (Rašević 1971).

In 1948, the Yugoslav rural population began to decline in size, but some features of a traditional agrarian society remained, nonetheless. Even in Slovenia and Croatia, large extended families lived and worked together under the new industrial conditions (Calic 2019). After World War II, the Yugoslav economy and society witnessed a profound transformation, especially after 1953. Intensive rural-to-urban migration, a rise in living standards, increases in women's employment beyond agriculture, educational expansion, and improvements in health services were all in progress (Rašević 1971). Yugoslavia experienced unprecedented change in the twenty years following 1945, with the most rapid urbanisation in all of Europe following World War II (Calic 2019).

By the 1960s, society could no longer be characterised as rural-traditional, while also not yet fully urban-industrial. The structural change brought about by industrialisation eased, but the problem of agrarian underemployment remained without a

1 According to the 1948 census, the proportion of unmarried women at age $75-79$ was 3.7 percent in all of Yugoslavia, but 14.5 percent in Slovenia (Rašević 1971: 67, Table 3). 
satisfying solution (Calic 2019). Meanwhile, many peasants and the post-war baby boomers entered the urban labour market. The resulting surplus of labour was one of the reasons why Yugoslavia was the only socialist country in Europe that tolerated and even promoted out-migration (Bonifazi/Mamolo 2004).

During the 1960s, Yugoslavia had crossed the threshold from an agrarian to an industrial society, and the population was wealthier than ever before (Calic 2019). Between 1950 and 1965, real income grew by about 80 percent, and the wealth gap with the Western industrial nations narrowed. This meant that "Yugoslavs no longer lived in Europe's poorhouse" (Calic 2019: 208) and Yugoslav society resembled Western Europe's more closely.

Yugoslavia's socialist self-management in many ways differed from other state socialist regimes in Europe. Rapid industrialisation during the 1950s (Horvat 1971) was accompanied by considerable rural-to-urban migration, and unemployment in contrast to other planned economies - became a chronic problem (Woodward 1995). Unemployment rates were higher in the least developed republics - Kosovo and Macedonia - and lowest in the two wealthiest ones, Slovenia and Croatia (G/igorov 2016). ${ }^{2}$

In the 1980s, Yugoslavia entered an economic recession. This was accompanied by a rise in foreign debt and inflation, and a decline in living standards. From the late 1970s onwards, the Yugoslav economy was faced with the unemployment upsurge caused by market-oriented economic reforms of the first half of the 1960s. Unemployment now affected not only unskilled rural workers, but also the skilled labour force (Woodward 1995).

The economic and social crises that followed the 1991 dissolution of Yugoslavia produced a sharp drop in living standards and a rise in social problems (KaporStanulović/David 1999). These changes brought about economic and social insecurity, worsened by an outbreak of wars. Recovery began in the 2000s, when all former Yugoslav countries once again had reached their 1989 GDP levels (Bolt et al. 2018).

\subsection{Family life in the Yugoslav countries}

The role of women in many Yugoslav countries during the first half of the twentieth century was shaped by patriarchal family and social relations, as well as by traditional morality based on the norms of the prevailing peasant society (Erlich 1966). The low status of women in the patriarchal peasant society before World War II included a traditional gender division of labour. Widespread illiteracy and traditional family values and customs resulted in high fertility. In such circumstances, children - and sons in particular - were regarded as highly valued labour force and as someone to continue the family line (Rašević 1971). Historically, Yugoslav women

2 In 1980, unemployment in Slovenia was 1.4 percent, 5.2 percent in Croatia, 15.8 percent in Serbia (excluding Voivodina), 14.1 percent in Bosnia, 14.7 percent in Montenegro, 21.5 percent in Macedonia, and 27.6 percent in Kosovo (Gligorov 2016: 19, Table 5). 
assumed a more submissive and subservient role than women in many other European countries (Springer 1986).

In many parts of Yugoslavia, a basic social unit of family life was the zadruga, a patriarchal family community. Before the twentieth century, it was the most common form of family organisation in the region, with members owning and working common land (Erlich 1966; Sklar 1974). The members of a zadruga were related by blood or marriage. Women were subservient to men and performed much of the hardest physical work (Springer 1986). The zadruga system conditioned early and universal marriage that was widespread throughout the region (Sklar 1974; Hammel 1975). Nonetheless, early trends toward social change from the nineteenth century continued in the first decades of the twentieth century. In parts of Yugoslavia where extended families were becoming rarer, there were more unmarried people, more women were using birth control, and abortions were more frequent (Calic 2019).

However, nineteenth and early twentieth century modernisation processes did not influence all areas equally (Erlich 1966). Regional fertility differences can be traced to the different cultural influences to which the particular republic was exposed. In particular, differences in social norms regarding marriage formation came to the fore. Social norms of marriage formation may have had their roots in economic and social circumstances. Fertility was highest in the least developed parts of Yugoslavia: Areas that were under Ottoman influence for a longer time, as well as areas in which the traditional zadruga remained intact. On the other hand, fertility was lowest in developed parts of the country, which were dominated by their northern and western neighbours, or had developed on their own (Rašević 1971). Certain ethnic characteristics may also have affected fertility levels. This is especially true of sociocultural factors, such as social customs, moral codes, or religious doctrines. Religious affiliation played an important role in political, cultural, and social life during the interwar period (Calic 2019). Its association with fertility possibly ran through marriage norms (age at marriage, prevalence of celibacy, remarriage of widows, etc.) or through a direct impact on the number of births (women's status in the family, changing attitudes about family size, religious norms of birth control, attitudes toward sexual life, etc.) (Breznik et al. 1972; Rašević 1971).

The impact of marital behaviour on fertility varied. In Macedonia and Kosovo, almost universal marriage was certainly one of the reasons behind high fertility. In other areas, the importance of marital variables was also noticeable, except in Slovenia, where widespread celibacy contributed to low fertility (Breznik et al. 1972). This phenomenon is related to the traditional inheritance system in Slovenia, which allowed only the oldest son and daughter to marry and bear children, while younger siblings remained unmarried if they did not find their own means of subsistence (Breznik 1991). A similar system was in place in parts of what is now Croatia, where more than 20 percent of women born during the late 1860s and early 1870s remained childless. On the other hand, childlessness was low in Kosovo, Macedonia, and parts of Serbia and Bosnia, where the family system followed different rules. In Slovenia, fertility rates were closer to those in Western Europe. High rates of unmarried women in Slovenia in cohorts born in the late nineteenth and early twentieth centuries were partly a result of changing social norms of marriage, and partly a 
result of high emigration rates of young men. At the same time, in Bosnia-Herzegovina, only 5 percent of adult women remained unmarried (Rašević 1971).

In socialist Yugoslavia, the traditional patriarchal family changed and disappeared. In the period immediately following World War II, many women in Yugoslavia resumed their traditional roles as wives and mothers, especially in rural areas (Jancar-Webster 1990). The trend toward secularisation accelerated after 1945. Apart from the well-known determinants associated with the demographic transition (industrialisation, changes in the economic structure of the population, urbanisation, increases in education, greater population, and social mobility), several important factors related to the revolutionary social changes during and after the war contributed to drops in fertility. These were related to women's status within the family; changes in family relations; changes in attitudes toward religion and other social institutions; and increases in parents' efforts to provide a better education for their children (Rasević 1971; Breznik et al. 1972). Patriarchal attitudes, values, and social relations eroded (Calic 2019), and changes in the social structure were of such a magnitude that they accelerated the process of changing attitudes toward family size, which began in Yugoslavia in the late nineteenth century (Rašević 1971). The dominant male role in marriage ceased to exist as it had before the war, and marriage started to become more and more of a partnership (Calic 2019). Socialist modernisation, consumerism, more education and increasing job opportunities for women promoted a slow but sure shift to more gender egalitarianism during the 1960s (Calic 2019).

The acceptance of gender equality was uneven in the Yugoslav population. Slovenia can be regarded as having been relatively progressive, with the least traditional gender roles, and the nuclear family as the norm (Woodward 1995). However, profound changes in gender relations did not occur in Bosnia-Hercegovina, Montenegro, or Macedonia, where the extended family was still typical (Woodward 1995).

Despite increasingly working outside the home, even in the late 1980s, women took greater responsibility for housework. Neither education, occupation, urbanisation, nor participation in the informal economy had a significant effect in reducing this. Only the presence of an older female in the household measurably reduced an employed woman's participation in the "second shift" (Massey et al. 1995). In almost all republics, women still worked the "second shift" in the household, and childcare facilities such as nurseries and kindergartens were lacking and widely unaffordable (TransMonEE Database 2019).

Today, young people in the Western Balkans have chosen conformity, rather than challenging traditional norms on family formation, because the family remains the main social safety net (Lerch 2018). Many features of the second demographic transition did not reach the majority of the population in the less developed regions. Former Yugoslav countries belong to regions with the highest share of young people who live in the parental home in Europe (Eurostat Database 2019). There are still high marriage rates in Kosovo and North Macedonia, and low extra-marital fertility in almost all regions except Slovenia (where it exceeds 50 percent). The mean age of women at first birth used to be very low from the 1960s to 1980s, comparable to other socialist countries (22-24 years of age). Since 1990, it increased more in Croa- 
tia (28.5 in 2017) and Slovenia (28.8) than in other regions (around 27 years of age in Kosovo and Bosnia-Herzegovina) (Eurostat Database 2019).

\subsection{Women's education and economic activity}

Many factors contributed to the weakening of the patriarchal model and the transformation of the traditional Yugoslav family throughout the twentieth century, but mass education and employment of women outside the household were especially important (Breznik et al. 1972). It was not until the early twentieth century that women started basic education in larger numbers in Serbia. The situation was very similar in Slovenia and Croatia, while in Bosnia-Herzegovina, Kosovo, and parts of Macedonia, girls' education was not only denied, but the state even allowed Sharia law until 1945 (Breznik et al. 1972). High illiteracy was closely associated with more traditional values and attitudes and, consequently, with higher fertility. The greatest increase in literacy happened in the early twentieth century in Slovenia. It was somewhat slower in Croatia and Serbia, and very slow in other countries (Rašević 1971). However, there were already some notable between-country differences in the early twentieth century. According to the 1921 census, the percentage of illiterate women was the lowest in Slovenia, but high in Serbia (44 percent) and BosniaHerzegovina (57 percent) (Somerville 1965). In the Kingdom of Yugoslavia, basic schooling was compulsory, at least formally, but not all children were covered by primary education. Girls, especially those who lived in poor regions, were often excluded from schooling (Somerville 1965).

Female education grew more slowly relative to other socialist countries (Woodward 1985), but there were huge regional variations, pointing to Yugoslavia's uneven economic development. In the early post-World War II years, the education of girls was still very modest. Schooling of girls became widespread in later decades, especially during the 1970 s. Women began to catch up in higher education statistics and increasingly attained tertiary education. They not only narrowed the gender gap in education, but also became equal with men in terms of their representation in higher education institutions (Woodward 1985).

The further expansion in female educational participation in the 1990s led to later childbearing as compared to the socialist era (Eurostat Database 2019), which is related to the so-called "postponement transition" (Sobotka 2011; Kohler et al. 2002). However, significant regional variations regarding female educational levels persisted. The similar proportion of women aged 20-39 with post-secondary education that was achieved in Serbia and Montenegro in 1990 (around 12 percent) was not achieved in the less-developed countries (Kosovo, North Macedonia, BosniaHerzegovina) until 2002 or later (Lerch 2018: Table 1). The relationship between education and fertility was probably mediated by economic and cultural circumstances. Rašević (1971) found that the link between education and fertility in Yugoslavia was strong, and that it was weakest in low-birth rate regions and strongest in middleand high-birth rate regions.

Female economic activity is another determinant that was often discussed among Yugoslav demographers (Rašević 1971; Breznik 1991) as a driver of fertility, espe- 
cially in republics with high fertility, in which social change and fertility decline were markedly faster only in urban areas. Later, when such changes spread to the rural population, the impact of women's activity on fertility rates diminished (Breznik et al. 1972). Before World War II, women were rarely in paid employment outside their households (Rašević 1971), a situation that changed after the war. Female employment continuously increased until the 1960s in non-agriculture sectors, faster than in any other European country (Calic 2019). Nevertheless, the pressure on women to join the labour force, typical to European socialist countries, was never present in Yugoslavia. Yugoslav women had lower labour market participation rates than women in other socialist countries. In the 1970s and 1980s, female employment figures were closer to the lower numbers found in Western Europe (Woodward 1985). The combined effect of preserved traditional attitudes toward working women, together with the chronic shortage of jobs (labour surplus), contributed to a lower participation rate for women in paid employment (Springer 1986). Married women had a lower attachment to the labour force, which indicates that traditional values might have discourage married women from working (Reeves 1990).

During state-socialism, Yugoslav republics and provinces developed economically at different rates, and this had a visible impact on women's lives. Women in wealthier republics (Slovenia and Croatia) prospered more than women in other regions (Reeves 1990). Slovenia was the most progressive republic, with the highest levels of female employment, and where the work of women outside their households has had the longest tradition. During this period, Slovenia even had one of the highest proportions of women in the total employed population in Europe (Mežnarić 1985).

In the 1990s and 2000s, the region underwent a substantial reduction in employment rates and a surge in job insecurity that hit women especially hard (Brunnbauer 2000). Relatively low economic activity rates (particularly among women), a large share of long-term unemployment, a shrinking working-age population, and high youth unemployment have remained dominant features of all countries in the post-Yugoslav era, with the exception of Slovenia. Female employment was low compared to the EU average, and unemployment rates in the 1990s and 2000s were among the highest in Europe (Eurostat Database 2019). Female labour market integration remains a key challenge for many countries in the region. Work-schedule flexibility is low, part-time employment is less common than in most (other) EU member states, and societal and cultural attitudes toward working women remain fuzzy.

\subsection{Fertility regulation}

Birth control and the prevalence of fertility regulation within marriage in Yugoslavia were major contributing factors in the differentiation of fertility rates between the republics (Rašević 1971; Breznik et al. 1972). Despite their relatively weak socioeconomic development in the early twentieth century, the populations of the Balkan countries adopted the practice of voluntary birth control within marriage more quickly than the rest of Europe (Botev 1988). Birth control began to emerge in the 
late nineteenth and early twentieth centuries in Slovenia and some parts of Croatia and Serbia (Rašević 1971). Due to the rise of literacy and education, the use of classical methods of contraception began in Slovenia in the late nineteenth and early twentieth centuries, alongside abortions as a means of terminating unwanted pregnancies (Breznik 1991). There is some evidence that the population of eastern Serbia, in some parts of Croatia, in Vojvodina, and in other areas accepted birth control in marriage, triggered by specific economic factors (Breznik et al. 1972). In Serbia, fertility decline started before any significant economic progress. Abortions performed by non-skilled persons were a common practice. A preference for small families emerged as an incentive to prevent land from being divided among multiple heirs. This economic motive was also widespread in other areas, for example, in Slavonia -the most eastern region in Croatia (Rašević 1971; Breznik et al. 1972).

Between the two wars, both the relative and absolute numbers of abortions increased (Rašević 1971; Breznik et al. 1972). Societal attitudes toward birth control during this period tended towards prohibition. Immediately following World War II, birth control gradually increased in the form of a large number of so-called "incomplete abortions" (self-induced or administered by non-professionals), for which women had sought professional help in healthcare institutions (Breznik et al. 1972). The first abortion regulation in 1952 allowed abortions only for medical and ethical reasons. Legislation that is more liberal entered into force in 1960, allowing women to have abortions legally for social reasons as well (Rasević 1971).

Socialist Yugoslavia was a trendsetter in its official support for women's rights, having put into its 1974 Constitution (Article 191) that "it is a human right to decide freely on childbearing" (Drezgić 2010). Most spouses accepted birth regulation as a part of their "lifestyle", mainly through abortions, which were very common in some regions. Abortion as a method of fertility regulation was used (often repeatedly) by women at all levels of educational attainment, in order to maintain the desired number of children (Drezgić 2010). Modern contraceptives were made available in Yugoslavia in the 1960s, but their spread was limited in all republics except Slovenia (Breznik 1991). The majority of women still relied on traditional contraceptive methods, such as coitus interruptus, and modern contraception was widespread only in Slovenia (Breznik 1991). After 1970, the adoption of new legislation on abortion led to a rise in the number of registered abortions. Some scholars assume that the liberalisation of abortion regulation meant that many previously illegal abortions could now be sought out legally (Breznik 1991).

The overall use of modern contraceptives was low and went in tandem with high abortion rates (Kapor-Stanulović/David 1999; Drezgić 2010). Throughout socialist Yugoslavia, except in Kosovo, almost half of all pregnancies ended in abortion (Kapor-Stanulović/David 1999). Abortion rates were comparatively very high in Yugoslavia (especially in Serbia); they were higher only in the Soviet Union (Drezgić 2010). Within Yugoslavia, abortion and contraceptive practice were least accepted in Kosovo (Breznik 1991).

After the dissolution of Yugoslavia in the 1990s, attempts were made to restrict reproductive rights and freedoms. This happened even though abortion rates declined significantly in all Yugoslav republics; the decrease was lowest in Serbia (Ka- 
por-Stanulovic/David 1999). With the advancement of nationalist ideologies in the 1990s, the birth and biological survival of the nation became the dominant theme of political discourse, and population themes were part of these ideologies (Drezgic 2010). For example, in 1990s Croatia and later, it was much more difficult to exercise the right to abortion, although the legislation itself had not changed in any significant way. As a result of a campaign in which the Catholic church and religious organisations started to advocate the "right to life" and pronatalism, many physicians refused to perform abortions (Kapor-Stanulovic/David 1999).

\subsection{Spurious population policies}

Little attention has been devoted to population policies and family planning programmes before the socialist period. In the first decades of the socialist period, authorities mostly neglected demographic issues (Drezgić 2010). Compared to the standards of that time in many other countries, Yugoslavia maintained a very liberal population policy (Calic 2019). Moreover, while other eastern European socialist countries opted for pronatalist policies (albeit in varying degrees), Yugoslavia endorsed a liberal principle of family planning, refraining from openly pronatalist measures (Drezgić 2010). In the mid-1960s, Yugoslavia was the only European country with a digressive scale for family allowances (Besemeres 1980). Child allowance payments were decentralised in the late 1960s. Higher benefits were paid in wealthier republics with lower fertility (e.g. Slovenia), and lower benefits were paid in poorer regions with higher fertility (e.g. Kosovo). However, these differences were not pronounced, and authorities in Kosovo introduced and even raised child benefits (Besemeres 1980).

Why did Yugoslavia not implement a pronatalist policy, like other socialist European countries, even though some republics and provinces already exhibited the lowest fertility rates in the world by the 1960s? Besemeres (1980) offers several possible explanations. The communists in Yugoslavia were more liberal than other socialist regimes, with no interest in interfering with family decision-making. In addition, in the 1960s, the country fell into a labour surplus, so there was no need for the federal government to addresses the possible future shortage of labour. Due to large regional disparities in fertility levels, the common pronatalist policy could easily become a politically sensitive issue, and selective introduction by republics and provinces could have become a potential source of inter-regional dispute. While the "homogenisation" of fertility rates became one of the normative principles of demographic discourse in Yugoslavia, it was never operationalised into specific policies at the federal level (Drezgić 2010). Besemeres (1980) also raised the question of whether Yugoslavia had any population policy at all, because at the time, it was one of very few countries in the world that included in its constitution the right to decide freely about childbirth.

However, in 1969, the Federal Assembly adopted a resolution on family planning, allowing the republics (provinces) to introduce and implement regionally differentiated population policy. Population policy was reconsidered in a 1975 developmental policy document, but not as a standalone topic (Breznik 1991; Drezgic 2010). In the 
1980s, regional authorities in low-fertility regions passed several resolutions and strategies with clearly proclaimed pronatalist objectives, but their implementation either failed or never happened (Breznik 1991).

In the 1990s, especially in Croatia and Serbia, there was an attempt to replace socialist family policies, which had aimed, at least formally, for gender equality, with traditional and pronatalist proposals (Drezgić 2008; Dobrotić 2018). The "demographic renewal" agenda in Croatia in the 1990s was most visible in the official government proposal to introduce the paid profession of a mother-caregiver. The aim was to provide all mothers with four or more children with an average salary (Dobrotic 2018). However, this idea of re-traditionalisation and withdrawal of women from the labour market was never implemented. In subsequent strategies on family and population policy, the pronatalist effort still dominated, but the notion of withdrawing women from the labour market weakened, and was rarely expressed explicitly (Dobrotić 2018). Nevertheless, in the 1990s and 2000s, while the pronatalist agenda was visible in public discourse and remained high on the list of policy priorities throughout the region, the lack of resources and economic crises challenged such initiatives. These findings are not surprising, as pronatalist "our nation is dying" agendas in the formulation of family policy have been present in many Central and Eastern European countries, especially after 2000 (Sobotka 2011). In comparison to other former Yugoslav countries, Slovenia has a relatively well-developed, comprehensive family policy, but research has not revealed any significant impact of individual family policy measures on individual fertility behaviour (Frejka/ Gietel-Basten 2016). In sum, promoting higher fertility in former Yugoslav countries has not been especially effective over the past few decades.

A search for all possible factors that might have contributed to cohort fertility declines in the seven former Yugoslav countries over a century-long period requires monograph-length explanation. These factors were and still are obviously numerous, and the exact degree of their influence cannot be properly assessed when the availability of appropriate data is limited. In this chapter, we have provided a thorough review of economic and societal changes that took place in Yugoslavia during the twentieth century, with an effort to describe in detail their possible impact on long-term cohort fertility developments.

Numerous and varied fertility determinants stemming from a complex interplay of political, economic and social forces are either region- or country-specific. Socio-economic and cultural change was, to a non-negligible extent, country-specific, but some countries nonetheless shared similarities. In regions where people began to practice birth control (including abortions) within marriage, fertility fell earlier, and the pace of its decline was faster. In other countries, modernisation and sociocultural changes came later, but proceeded more quickly. This chapter has provided a multitude of partial explanations of fertility decline over many generations, but some fertility determinants may have remained unmentioned. Nevertheless, we rely on this framework to analyse cohort fertility behaviour in former Yugoslav countries in the following chapters. We can hypothesize that fertility control within marriage greatly contributed to the fertility decline in former Yugoslavia. Marital fertility decline had a predominant influence on the decline in overall fertility levels 
in the more developed republics. A conscious adjustment of family size to changing economic and social circumstances can be viewed as the main explanation. Instead of producing change, as fertility theories might suggest, cultural variables prevented change in less developed Yugoslav regions, where ideational shifts were hampered by strong religious influences. In less developed agrarian societies (Kosovo, Bosnia and Herzegovina, Macedonia), children were still of high economic value to their parents. The lowest completed fertility levels can be found in regions where the features of the second demographic transition were most visible (Slovenia, Croatia, parts of Serbia). The nature of the fertility decline in Yugoslavia and the resemblance of fertility dynamics in some of its constituent states thus indicate that clusters of former Yugoslav countries share similar fertility histories. In the following analysis, we explore this hypothesis and investigate partial indicators of fertility by birth order in an attempt to confirm it.

\section{Data and methods}

To answer our research questions, we employ a comparative perspective, and construct a range of census-based cohort fertility indicators. These include completed fertility rates $(C F R)$, parity progression ratios $\left(P P R_{i-1, i}\right)$ and parity distributions $\left(p_{i}\right)$. We use data on women born between 1868 and 1973. Within this timespan, we cover the reproductive careers of women who were giving birth over a period ranging from the end of nineteenth century through the entirety of the twentieth century, including both world wars and the 1950s baby boom, up to the post-socialist transition era.

\subsection{Census data on parity of women}

Two censuses were performed in Yugoslavia before World War II, in 1921 and 1931, but these did not include questions on the number of births. The census prepared for 1941 was not conducted due to the outbreak of war. The question regarding the number of children a woman has had was introduced in the 1948 census and was retained in all subsequent ones, conducted in roughly tenyear intervals. The question, which was asked to all women of age 15 and older, followed the UN-recommended wording: "How many children have you ever born alive?" All post-war censuses were based on the permanent (de jure) population. The international recommendations for definitions were applied to the greatest possible extent (Breznik 1980). During the Yugoslav era, the census was always carried out in all federal republics simultaneously; after the breakup, dates varied. We use census data from the last three census rounds (around 1991, 2001 and 2011), complemented with results from the oldest available census, from 1948, as well as other censuses performed in 1961, 1971 and 1981 in former Yugoslavia, depending on their availability (see Table 3). In Kosovo, no census was carried out between 1981 and 2011; data from the 1991 census were highly unreliable because of a boycott among the Kosovar - predominately ethnic Albanian - population of the census performed by the then-Serbian 
administration. In North Macedonia, the last census was performed in 2002. We use the tabulation of women by birth cohort (or age) and the number of children born. Data from the 1948 census are available only by 5 -year age groups, but we decided to include them in order to cover the cohorts born in the nineteenth century and broaden our analysis to the cohorts born before the start of the demographic transition. Data from consecutive censuses were merged to the continuous time series using local polynomial regression fitting. ${ }^{3}$ The data for Croatia are displayed as an example in Fig. 1).

Tab. 2: Overview of the analysed countries and data sources

\begin{tabular}{lccccc}
\hline Country & Code & Analysed censuses & \multicolumn{3}{c}{ Population (millions) } \\
& & & C 1948 & C 1991 & 2018 \\
\hline Bosnia-Herzegovina & BIH & $1948,1961,1971,1981,1991,2013$ & 2.6 & 4.4 & $3.5^{*}$ \\
Croatia & HRV & $1948,1961,1971,1981,1991,2001,2011$ & 3.8 & 4.8 & 4.1 \\
Kosovo & RKS & $1948,1961,1971,1981,2011$ & 0.7 & 2.0 & 1.8 \\
North Macedonia & MKD & $1948,1994,2002$ & 1.2 & 2.0 & 2.1 \\
Montenegro & MNE & $1948,1991,2003,2011$ & 0.4 & 0.6 & 0.6 \\
Serbia & SRB & $1948,1961,1971,1981,1991,2002,2011$ & 5.8 & 7.6 & 7.0 \\
Slovenia & SVN & $1948,1991,2002,2011$ & 1.4 & 1.9 & 2.1 \\
\hline
\end{tabular}

Source: Population censuses of Yugoslavia (1948-1981) and of respective countries since 1991. Population in 2018 is taken from the Eurostat Database (2019). Population data for Bosnia-Herzegovina comes from the 2013 census.

The census data on the number of children born are, by nature, retrospective. We analyse the responses of women aged 40-80 at the time of the census interview, as younger women may still have additional children, while women older than 80 years were not used for the analysis because of selectivity due to mortality, and because the underreporting of deceased children could influence the results (United Nations 1983; Van Bave/ 2014). Various studies have identified a higher mortality of childless women, women giving birth at a very young age and of women with four or more children (as summarised in Barclay et al. 2016). However, at ages up to 80, the selectivity by parity is generally negligible (Hurt et al. 2006). Another phenomenon that can affect the quality of retrospective census data is external migration, which was quite high in certain periods of Yugoslav history. Andersson and Sobolev (2013: 352-353) found that: "the omission of individuals who emigrated or died rarely results in more than a minor overestimation of fertility rates (...) in population[s] with moderate or low levels of out-migration", as the "migration rates are typically lower for parents than for nonparents".

Similarity between different censuses for the same country is an important indicator of data quality. Generally, there is a very good match in the summary indica-

3 For the local polynomial regression fitting, we employed loess smoothing in $\mathrm{R}$ with the second degree of the polynomials and with the parameter $\alpha=0.20$. 
Fig. 1: Completed cohort fertility rate in Croatia according to the 1948-2011 censuses, and the fitted value used for analysis (dashed black line), cohorts 1868-1971

Completed cohort fertility

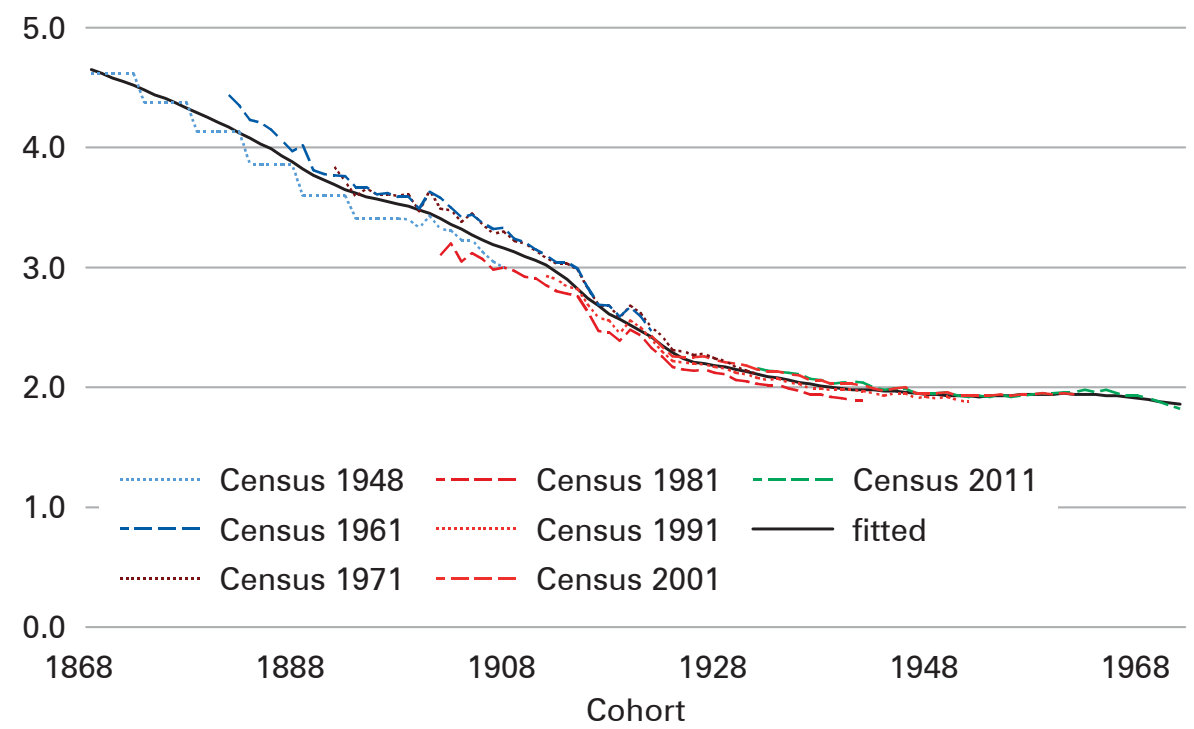

Source: Own calculations based on data from population censuses

tors of fertility calculated from various censuses in most of the analysed regions. There is an exception for the 1948 census, which shows a lower level of cohort fertility (Fig. 1) and a higher proportion of childless women than later censuses do (1961 and 1971), especially for Serbia, Croatia, and Bosnia-Herzegovina (Breznik 1972). Even if the 1948 census is not fully comparable, as the data only come from 5-year age group tabulations, we are not fully aware why such a difference exists, as it cannot be explained by differential mortality or migration. The Croatian 1981 census shows a lower level of fertility (Fig. 1), comparable to the 1948 census, but not fully comparable to other censuses. However, the effect on the overall level of cohort fertility and other analysed indicators is negligible.

\subsection{Completed cohort fertility, parity progression ratios and parity composition}

The basic summary indicator of cohort fertility level is the indicator of completed cohort fertility rate $(C F R)$, and completed cohort fertility rate by birth order $i\left(C F R_{j}\right)$, which is defined as:

$$
C F R_{i}=i * W_{i} / W
$$


where $i$ stands for birth order (parity), $W_{i}$ for number of women of given parity, and $W$ for total number of women (in a given cohort). CFR $i$ is the average number of children of birth order $i$ born to women from a given cohort.

For each birth cohort analysed, the CFR can be defined as the sum of parityspecific CFRi:

$$
C F R=\sum_{i} C F R_{i}
$$

Parity composition is expressed by the proportion of women of a given parity:

$$
p_{i}=W_{i} / W
$$

The parity progression ratios $(P P R)$ to first birth and to higher birth orders are given as:

$$
\begin{aligned}
& P P R_{0,1}=C F R_{1} \\
& P P R_{i-1, i}=\frac{C F R_{i}}{C F R_{i-1}} \text { for } i>1
\end{aligned}
$$

We combine data on the sixth and further births, computing an indicator of the progression rate from the fifth and higher-order births to the sixth and higher-order births:

$$
P P R_{5+, 6+}=\frac{C F R_{6+}}{C F R_{5+}}
$$

The other way around, it is possible to obtain completed cohort fertility from parity progression ratios as:

$$
C F R_{i}=\prod_{j=1}^{i} P P R_{j-1, j}
$$

for the highest parity: $C F R_{6+}=\prod_{j=1}^{5} P P R_{j-1, j} * \frac{P P R_{5+, 6+}}{1-P P R_{5+, 6+}}$

$$
C F R=\sum_{j=1}^{\text {imax }} \prod_{j=1}^{i} P P R_{j-1, j}
$$

In the second stage, we group the countries into three different clusters based on fertility levels. In order to better understand the differences between the clusters, as well as the similarities within them, we use decomposition of differences between completed cohort fertility rates of the clusters into the contribution of parity progression ratios. We employ a method used by Zeman et al. (2018), which build 
upon Barkalov (1999) (for details, see the Appendix). All calculated indicators are provided in the supplemental file.

\section{$4 \quad$ Results}

\subsection{Completed cohort fertility and country clusters}

The completed cohort fertility of women born between 1868 and 1973 in the respective republics of former Yugoslavia is depicted in Figure 2. The oldest available data reveal relatively a high fertility rate of populations before the start, or just at the start, of the demographic transition from high to low fertility and mortality. In the 1880 cohort, the level of fertility varies between 4 and 6 children per women (Table 4). In some countries (Serbia, Slovenia, Croatia), the decline is already under way, while in others, the fertility level is maintained at around 6 children per woman until cohort 1900. Around cohort 1930, the fertility level in Serbia drops below 2 children per woman, closely followed by Croatia and Slovenia. At that time, the fertility decline in Bosnia-Herzegovina, North Macedonia, and Montenegro is also well under way, at around 3.5 children per woman. Only Kosovo retains the pre-transition

Fig. 2: Completed cohort fertility rate in former Yugoslav countries, cohorts 1868-1973

Completed cohort fertility

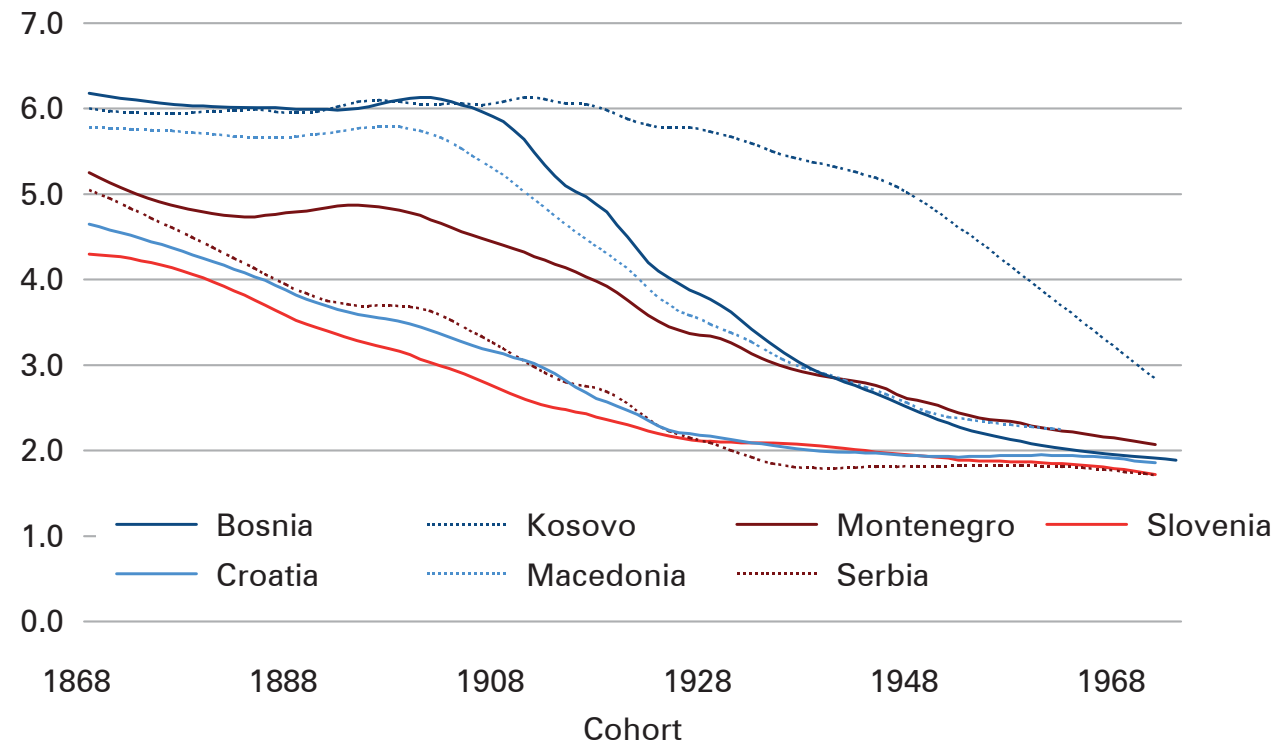

Source: Own calculations based on data from population censuses 
Tab. 3: Completed fertility rate of cohorts 1870-1970 by former Yugoslav country

\begin{tabular}{lcccccccccccc}
\hline Country & 1870 & 1880 & 1890 & 1900 & 1910 & 1920 & 1930 & 1940 & 1950 & 1960 & 1970 \\
\hline Croatia & 4.6 & 4.2 & 3.7 & 3.4 & 3.1 & 2.5 & 2.1 & 2.0 & 1.9 & 1.9 & 1.9 \\
Serbia & 4.9 & 4.4 & 3.8 & 3.7 & 3.1 & 2.5 & 2.0 & 1.8 & 1.8 & 1.8 & 1.7 \\
Slovenia & 4.3 & 4.0 & 3.4 & 3.1 & 2.6 & 2.3 & 2.1 & 2.0 & 1.9 & 1.9 & 1.7 \\
Bosnia-Herzegovina & 6.1 & 6.0 & 6.0 & 6.1 & 5.6 & 4.5 & 3.6 & 2.8 & 2.4 & 2.1 & 1.9 \\
North Macedonia & 5.8 & 5.7 & 5.7 & 5.7 & 5.0 & 4.1 & 3.4 & 2.9 & 2.4 & 2.3 & - \\
Montenegro & 5.1 & 4.8 & 4.8 & 4.7 & 4.3 & 3.8 & 3.3 & 2.9 & 2.5 & 2.3 & 2.1 \\
Kosovo & 6.0 & 6.0 & 6.0 & 6.1 & 6.1 & 5.9 & 5.7 & 5.3 & 4.8 & 3.9 & 2.9 \\
\hline
\end{tabular}

Source: Data from population censuses

level of 5.7 children per woman. Since the generations of the 1930s, the fertility remained around 2.0 in low-fertility republics, joined by the three higher-fertility countries over the next 30 cohorts. Fertility in Kosovo starts declining considerably only around cohorts 1940-1950, while still retaining the highest fertility rates in Europe.

The nature of the fertility decline and the similarity of the trends indicates that there might be clusters of former Yugoslav countries that share similar fertility histories. In the following analysis, we explore this hypothesis, investigate the partial indicators of fertility by birth order, and attempt to confirm it. This paper further analyses the mechanism of changes in cohort fertility in terms of parity progression ratios and the consequences on the parity composition of families, with a focus on the change between cohorts 1880, 1920 and 1960. We start by defining three clusters of countries: two clusters of three countries each, and Kosovo as a separate case.

The first cluster consists of Croatia, Serbia, and Slovenia, who already had relatively low levels of cohort fertility (around two children per woman) by cohort 1930 and maintained these levels throughout the analysed cohort span. Women born in 1970 had slightly lower levels of fertility, from 1.72 (Serbia) to 1.85 (Croatia). We label this cluster the low-fertility cluster.

The second identified cluster consists of North Macedonia, Montenegro, and Bosnia-Herzegovina. Here, the fertility level steadily declined from high levels around 6 children per woman among cohorts born in 1900 and converged close to the levels of the first cluster by the cohorts born in the 1960s. Higher fertility - over two children per woman - persists in Montenegro and North Macedonia. However, for North Macedonia we need to rely on an older census (2002), and newer figures for cohorts born in the late 1960s are not available. The lowest fertility level was recently recorded in Bosnia-Herzegovina (1.92 for cohort 1970). We label this cluster the high-fertility cluster. Montenegro used to have lower fertility rates among the oldest cohorts, comparable to the countries of the first cluster, but subsequently, the levels stagnated and caught up with those of the other two high-fertility countries. 
Fig. 3: Dendrogram of the similarity of regions according to cohort fertility patterns (PPR of cohorts 1868-1962), based on hierarchical cluster analysis

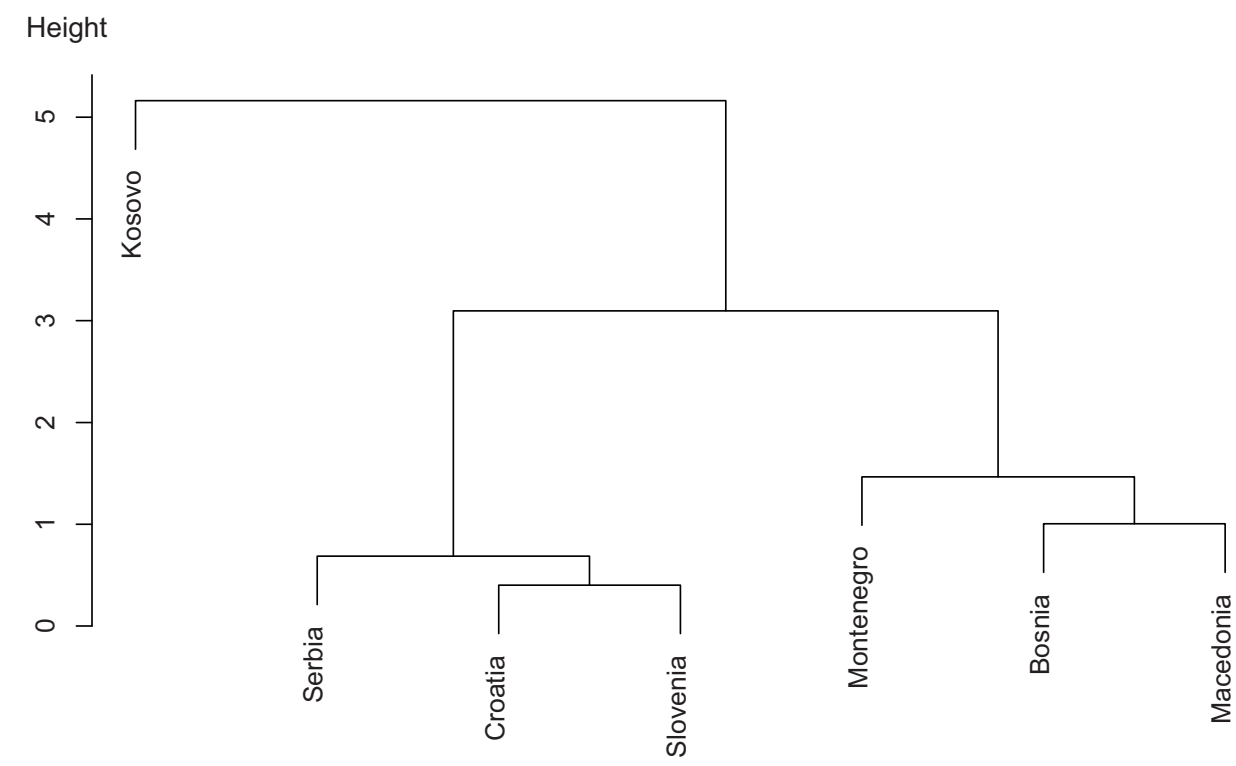

Source: Own calculations

The third cluster is solely made up of Kosovo, with levels of cohort fertility that are still comparatively very high in the European context. The level was above five children per woman among cohorts born in the 1930s, followed by an almost linear decline of around 0.1 children per generation. Generation 1970, then, went just below three children, with the decline likely to continue in further cohorts. This clustering was conducted via hierarchical cluster analysis ${ }^{4}$ based on the similarities in respective parity progression ratios for cohorts 1868-1962 (Fig. 3).

\subsection{Parity composition of women}

The most frequently used cohort fertility summary indicator after the CFR is cohort childlessness. Figure 4 reveals an interesting fact about fertility in the nineteenth century: childlessness in many regions was in fact much higher than in contemporary cohorts. This is especially striking for Slovenia, where census data indicate that more than one-quarter of women from the 1868 cohort remained childless, compared to about 12 percent of women from the 1973 cohort.

Childlessness dropped to particularly low levels during communist times, with only around 5 percent. Toward the youngest cohorts, childlessness again increases at a similar pace across regions, and with the highest level now in Montenegro

4 Function hclust in R. 
Fig. 4: Cohort childlessness, cohorts 1868-1973

Proportion of childless women

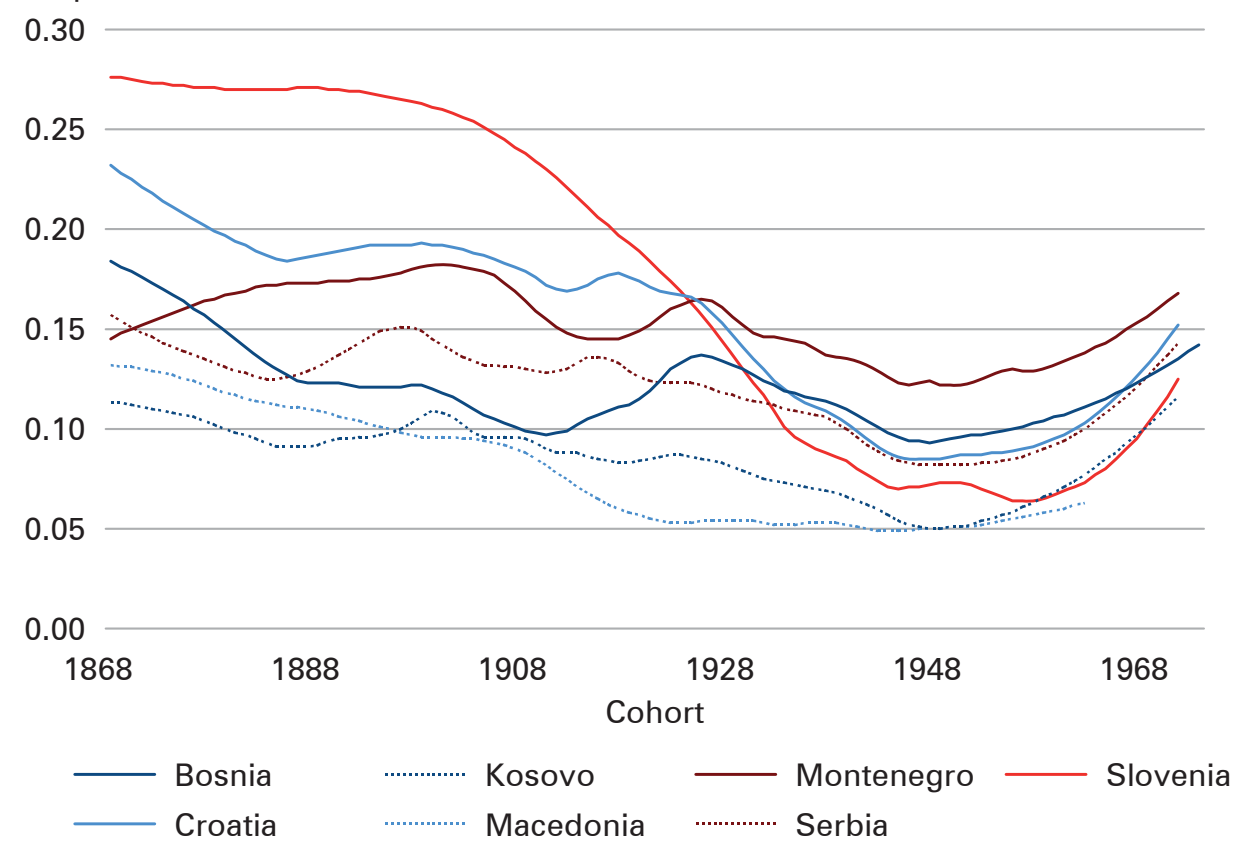

Source: Own calculations based on data from population censuses

(17 percent in cohort 1971), while childlessness is lowest in North Macedonia (7 percent in 1962 cohort and slowly increasing).

From this point of view, we found that childlessness does not follow the three previously defined clusters. However, childlessness - which is complementary to the parity progression to first birth - forms only part of the entire cohort fertility level. When looking at the proportion of women by number of children in the bigger picture (Fig. 5), we identify higher parities that show considerable similarities within the clusters. In the low-fertility cluster, there is a noticeable decline of large families of three or more children, and a strong focus on the two-child family. In Serbia, more than 60 percent of women born in the mid-1950s ended up with exactly two children, and around 55 percent in Croatia and Slovenia. This is comparable to some of the countries of Central-Eastern Europe, where the two-child family was very popular in communist times and remains the most common family arrangement (Frejka 2008; Sobotka/Beaujouan 2014). From the second cluster of countries, Bosnia-Herzegovina and North Macedonia have a more pronounced two-child family norm, while in Montenegro, the most preferred number of children was three or more.

Overall, the proportion of women with one child increased, especially in the lowfertility cluster, while the proportion of larger families decreased - though still relatively high - in the high-fertility cluster. 
Fig. 5: Share of women by number of children, cohorts $1880,1920,1960$

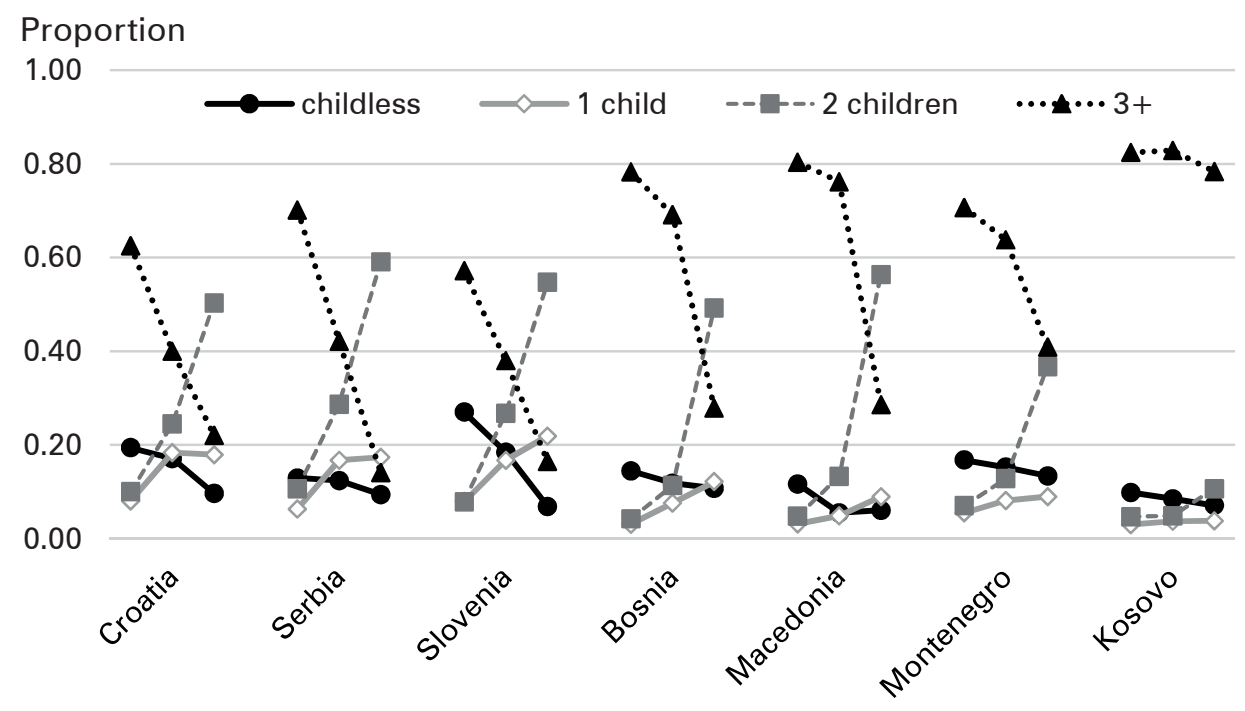

Source: Own calculations based on data from population censuses

Fig. 6: $\quad$ Proportion of women with six or more children, cohorts 1868-1973 Proportion

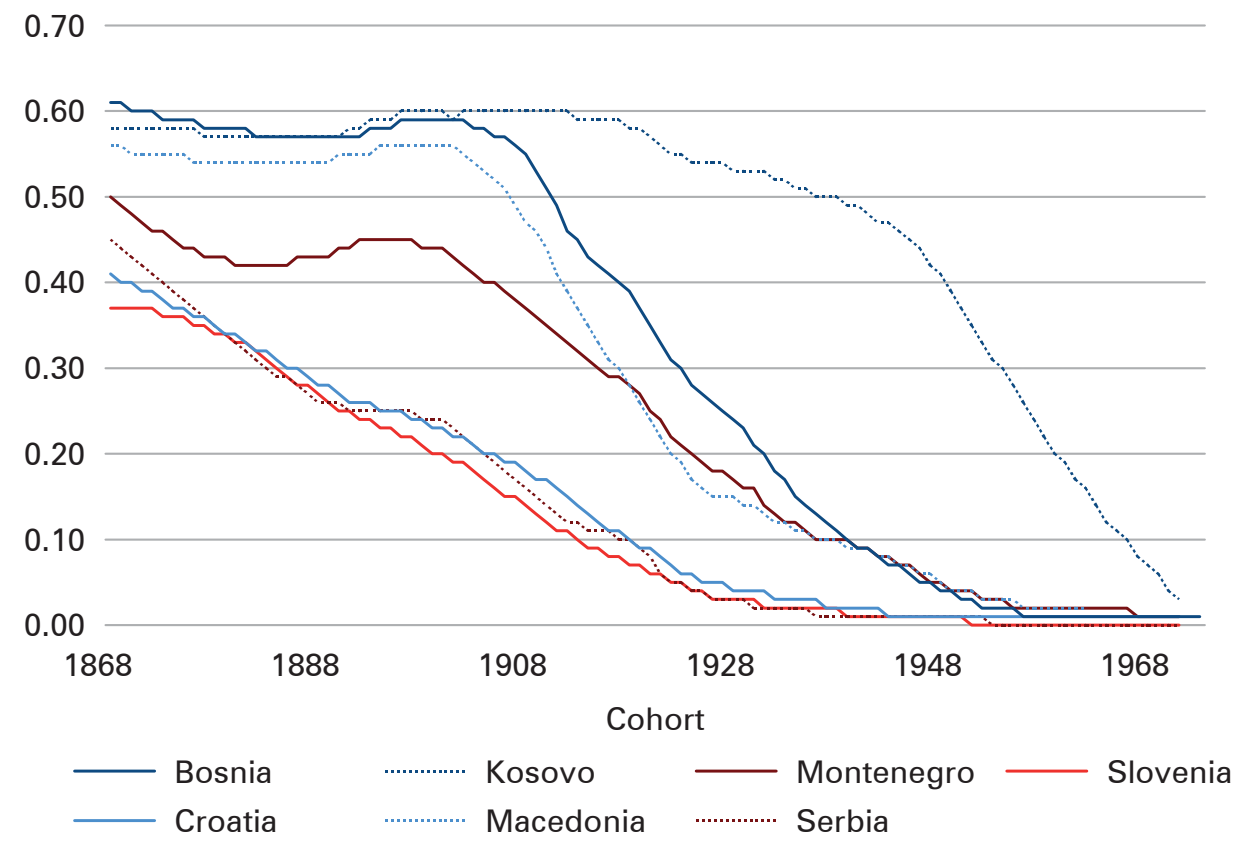

Source: Own calculations based on data from population censuses 
If we were to pick up one parity that drives the fertility decline, as well as the differences in the paths of decline between the countries and the clusters, it would be the parity $6+$ (women with six or more children). Depicted in Figure 6, it follows the paths of total fertility decline very closely (Fig. 2). While in the low-fertility cluster the proportion of women with $6+$ children quickly decreased from 40 percent around cohort 1870 to below 10 percent in cohort 1920, the proportion was still above 60 percent in other regions, until cohorts born in the early twentieth century (and more than half of all women in Kosovo had six or more children until cohort 1937). Six was the modal value of children in all regions before it changed directly to two children. In Slovenia and Croatia, for a few cohorts around 1900, the modal number of children was zero. In Montenegro and North Macedonia, this figure was three for a limited number of cohorts born around 1925. In Kosovo, the modal number recently dropped to four and subsequently to three.

\subsection{Parity progression ratios and parity composition of women}

The low-fertility cluster of Croatia, Serbia and Slovenia is also very homogeneous in terms of parity progression ratios. While PPR01 and PPR12 are quite high and stable, PPR23 and PPR34 went down almost simultaneously in all three countries (Fig. 7). This development led to the aforementioned dominance of the two-child family.

Fig. 7: Parity progression ratios to $1^{\text {st }}, 2^{\text {nd }}, 3^{\text {rd }}$ and $4^{\text {th }}$ birth, cohorts 1880,1920 , 1960

Parity progression ratios

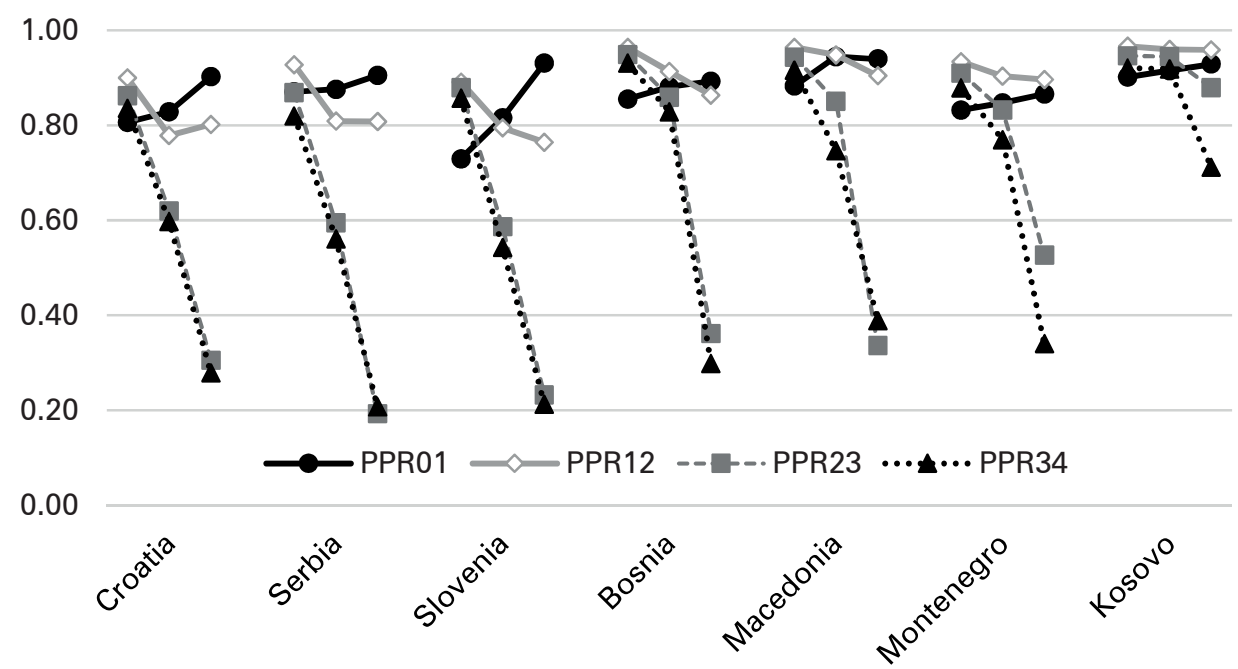

Source: Own calculations based on data from population censuses

In the high fertility cluster of Bosnia-Herzegovina, North Macedonia, and Montenegro, the situation is not particularly homogeneous. Parity progression ratios developed in more varied ways, and while PPR34 (and higher) had already declined 
Fig. 8: $\quad$ Parity progression from second to third child, cohorts 1868-1973 Parity progression ratios

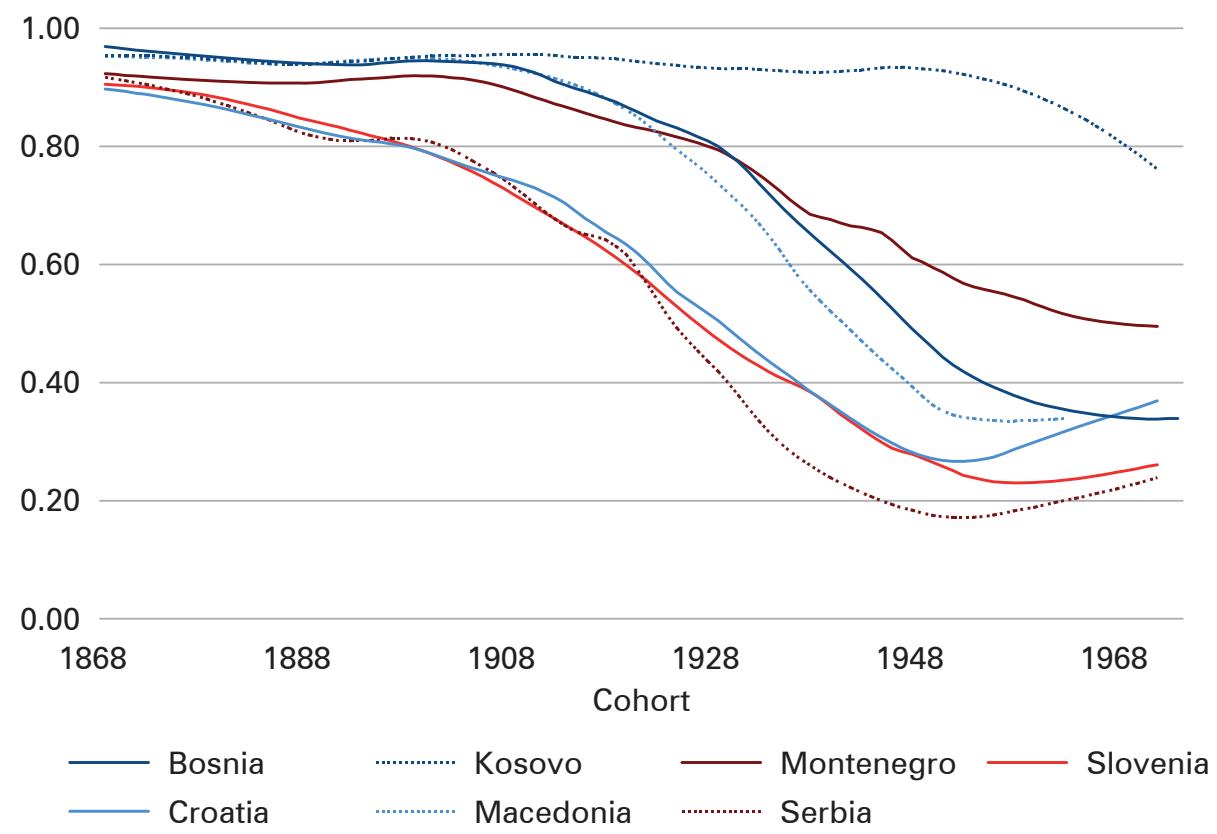

Source: Own calculations based on data from population censuses

considerably, lower parity progression ratios follow differing patterns. This is especially apparent in PPR23 (Fig. 8). While in Bosnia-Herzegovina and North Macedonia the parity progression ratio toward the third birth declined to very low levels comparable to Croatia, in Montenegro, the decline is somewhat slower, which is manifested by a lower proportion of women with two children, and a higher proportion with three children.

In fact, progression to third births is the most distinctive factor of fertility differentials in the youngest cohorts between the regions and clusters of former Yugoslavia, as we will show in the following section.

The special case of Kosovo is also apparent from the high cohort fertility. This is maintained by high, though declining, progression ratios to high parities. PPR23 in particular is still very high at 0.76 for the 1971 cohort (Fig. 8), and PPR34 is still at 0.5. PPR01 and PPR12 stay close to $0.90-0.95$, which leads to a very low proportion of women with one child, and the proportion of women with two children is also very low.

\subsection{Country clusters and decomposition}

In the final analytical section of this study, we formally investigate the country clusters defined above and decompose the difference in overall fertility level between them into the effect of parity progression ratios. Figure 9 includes the completed 
Fig. 9: Completed cohort fertility by country clusters

Completed cohort fertility

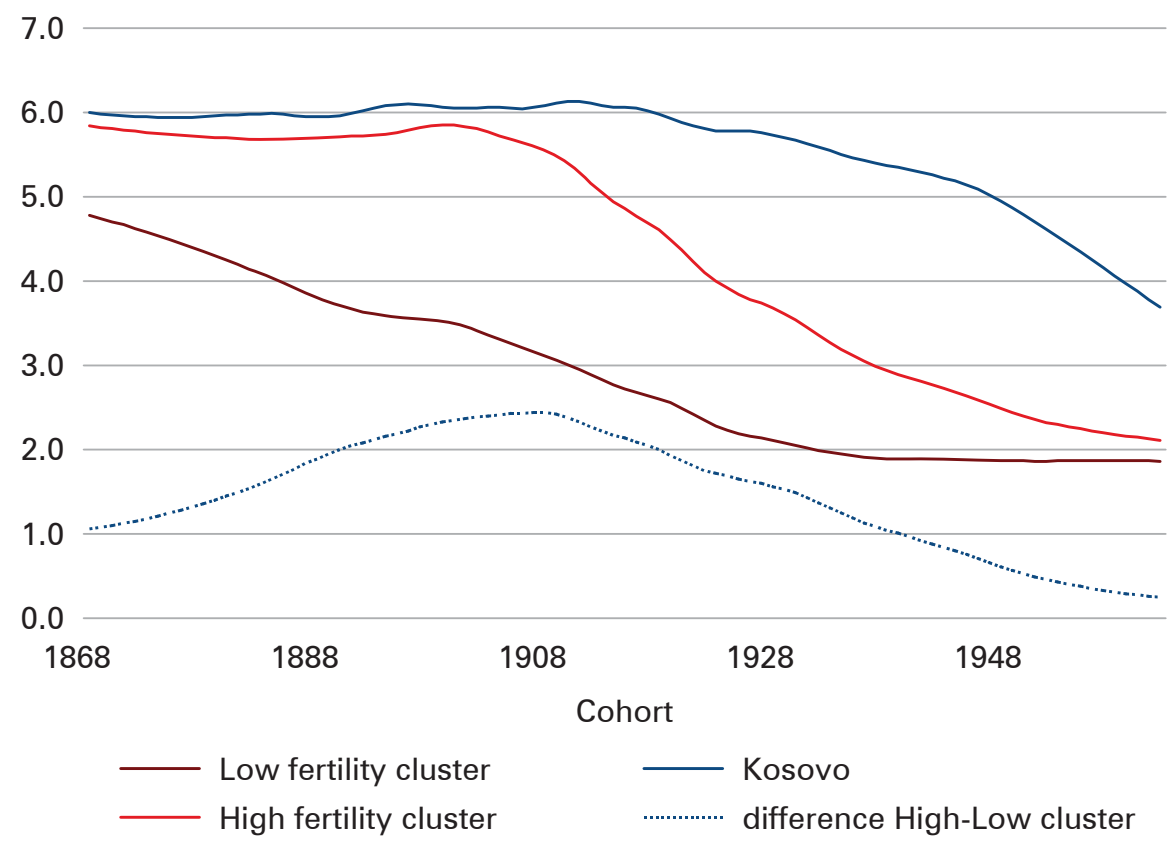

Source: Own calculations

cohort fertility in the three defined clusters, computed as the female population weighted mean of country CFRs in the given cohort. The development in the clusterspecific CFRs is obvious, as discussed above. We now decompose the difference in CFRs between the high- and low-fertility clusters (depicted by the red line) into the effect of differences in PPRs, using the method defined in the Appendix. We decompose the difference between the low- and high-fertility clusters, omitting Kosovo.

The results of decomposition are given in Figure 10. In the oldest cohorts, when the difference in CFR was around 1.0, all parities had a similar effect on the difference, with PPR01 having the largest effect $(0.28)$, and others contributing 0.13 to 0.18 . This changed in the subsequent decades, when the fertility level in the low-fertility cluster dropped, while stagnating in the high-fertility cluster. Cohorts 1900-1910 then experienced the widest difference, 2.4. Here, the most important factor was the progression toward the highest parities, which accounted for 0.64 , or 27 percent, of the differences. Additionally, progression to the third and fourth parity contributed heavily, with both around 0.45 . The contribution was weaker at lower parities. In the last observed cohort of women born in 1962, the difference was just 0.25 . Here, the most important factor was the progression from the second to third birth (0.13), PPR01 was practically unchanged, PPR12 contributed by 0.09 , and contributions of higher parities were negligible. 
Fig. 10: Decomposition of the difference between completed fertility in country clusters

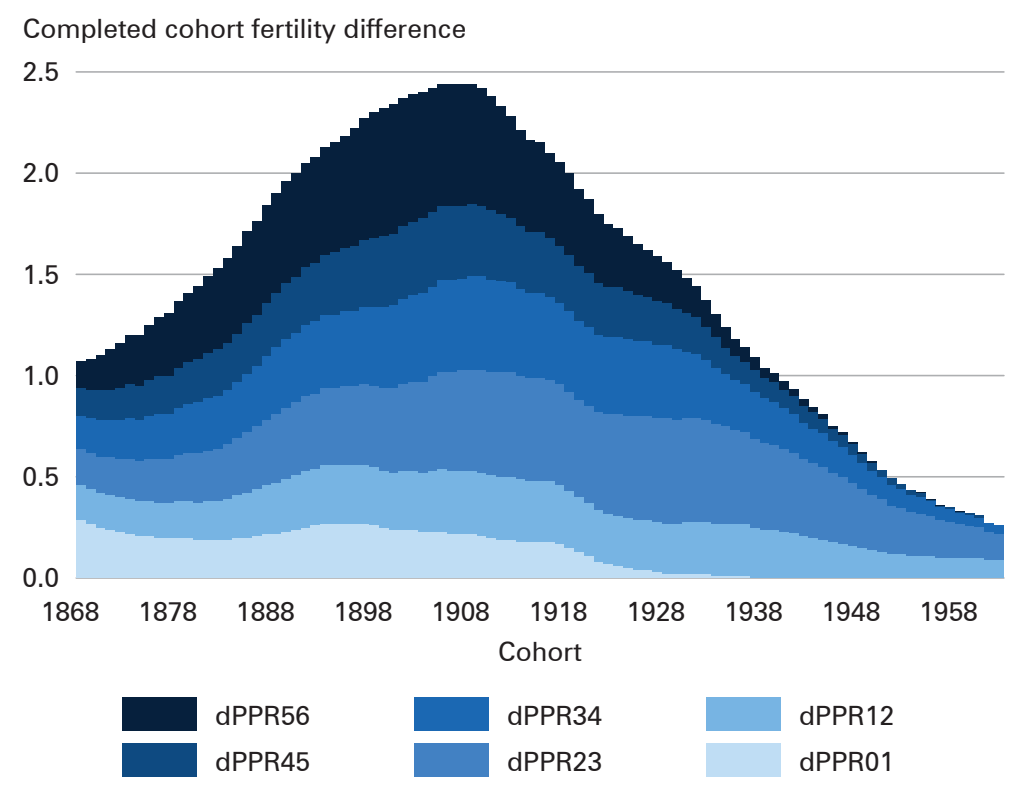

Source: Own calculations

\section{$5 \quad$ Conclusions}

The goal of this study was to bring to light the overall picture of cohort fertility decline in the regions of former Yugoslavia and to discuss it in a broader socio-cultural and economic context. Formally, the paper aimed to respond to three research questions concerning cohort fertility based on the available census data. In this conclusion, we summarize the results of our formal data analysis and put these findings into the context of broad historical, political, economic, and social factors. We are aware that the connection between the analysis results and the context is not causal, as the analysis is based on macro-data, and cannot identify the exact statistical link between broader socio-economic factors and fertility. This would require much more detailed survey data, or individual census data, which are not available for such a broad geographical and temporal space. Therefore, our conclusion is an overview of parallel contextual phenomena, rather than one of causal determinants.

\subsection{Trends and patterns of cohort fertility in the former Yugoslav countries}

In the descriptive part of the paper, we analysed census data that reveal rapid cohort fertility declines from levels of 5-6 children per woman born in 1860 to around 2 children in more recent cohorts (1960s). This decline has also been identified elsewhere in Europe and in other developed countries (Frejka/Sardon 2006; Frejka 
2008; Zeman et al. 2018). In the Yugoslav context, it is interesting that the various regions progressed along different paths, while also displaying some specific features regarding parity composition of women. For example, very high childlessness in old cohorts of Slovenian women was related to the traditional inheritance system, which encouraged the oldest son (the heir) to marry and have children, while younger siblings could continue to inhabit the family property if they remained unmarried. On the other hand, childlessness was low in Kosovo, North Macedonia, and parts of Serbia and Bosnia, where the family system followed different rules (Zadruga, universal marriage).

The transition from an agrarian society to industrialisation did not come to Yugoslavia in a uniform manner. In northern parts of Yugoslavia - such as Slovenia and Croatia, which were part of the Habsburg monarchy - and also some parts of Serbia, this transition started earlier than in underdeveloped parts of Kosovo, Montenegro, and Macedonia. In the socio-economic sphere, this was accompanied by increases in women's employment outside agriculture, educational expansion, a rise in living standards, intensive rural-to-urban migration, and improvements in health services. In census data, it is identified by a steeply decreasing proportion of women with six or more children from the 1860 cohorts onwards in Croatia, Slovenia, and Serbia, while in other parts, the decline started only with women born after 1900 . While there were differences in the timing of economic development throughout the regions before World War II, Yugoslavia never before experienced such profound changes as it did during the two decades after 1945. However, similar to the Princeton project findings (Coale/Watkins 1986), Breznik (1991) argues that for many regions, cultural factors were much more important than economic ones, and that even less-developed regions could be further along in the pace of demographic transition and fertility decline than economically better-off and developed regions with more rigid cultural norms. For example, ethnic composition and religion have a strong influence through local traditions on marriage dynamics, family patterns, and family planning, including birth control, contraception, and abortion. Very high abortion rates probably pushed fertility levels down further in Serbia.

Female economic activity is strongly related to female educational expansion and the eradication of illiteracy. Women entered basic education in larger numbers in Serbia, Slovenia, and Croatia from the early twentieth century onwards. In Bosnia-Herzegovina, Kosovo, and parts of Macedonia, girls' education was denied even until World War II. High illiteracy was closely associated with more traditional values and attitudes and, subsequently, with higher fertility. Higher education of women generally only started after World War II, and more intensively only in the 1970s.

\subsection{Country clusters: Homogeneity within Yugoslavia's heterogeneity, persistent divergence or convergence?}

In the analytical part of this paper, we clearly identified three clusters based on similarities in cohort fertility development. The first cluster contains Slovenia, Croatia, and Serbia, countries that are closer to Western and Central Europe, both geographically and culturally. Here, demographic transition started earlier than in the 
second cluster, which consists of Bosnia-Herzegovina, North Macedonia, and Montenegro. This was also apparent from the period fertility levels (Table 1), where the decline in Serbia, Croatia, and Slovenia was already underway at the beginning of the twentieth century, while in other parts it came much later - in some places, only in the 1950s. When we look at the differences in 1950, the total fertility rate varied between 3 and 7 children per woman: In low fertility countries, it was around 3 to 3.5, in Montenegro it was higher than 4; in Bosnia-Herzegovina it was 5; in Macedonia it was 6; and in Kosovo, it was 7 children per woman.

The gap between the two clusters' overall cohort fertility levels was largest in the 1900-1910 cohorts, when it was 2.4 children. This was a considerable change compared to nineteenth-century cohorts, where the difference was only around one child, and the cohort fertility levels were much higher. This fact indicates that the demographic transition started about 30 years earlier in the low-fertility cluster than in the high-fertility cluster. However, with fertility hitting very low levels in the most recent cohorts, the high-fertility cluster is catching up, and the most recent gap for the 1962 cohort amounts to only 0.25 children per woman. We may conclude that there is a continuing convergence in fertility levels, with the persisting gap related to children of the third birth order, and the parity progression from the second to the third child. In other words, the two-child family model is much more prevalent in the low-fertility cluster.

There is a different situation in Kosovo - even though we identified a decline in fertility levels, especially among high-birth orders, the progression toward the third and fourth child is still so strong and unique in the European context that we can hardly talk about convergence. The reasons for this are both economic and cultural. On the one hand, we have low economic development, an unclear and generally pessimistic political situation, persisting agrarian settlement, poor female education, and low female economic activity; on the other hand, we have deep-rooted traditions, the prevalence of conservative family values within a Muslim population, a low acceptance of birth control and modern contraception, and high marriage rates.

As for future developments, we can expect a further convergence of high-fertility cluster regions to low-fertility ones towards a situation that will most likely resemble that of Central and Eastern European countries, with cohort fertility levels at around 1.75-2, moderate childlessness at around 10-20 percent, and the accentuated model of two-child families (Zeman et al. 2018).

In fact, some of most recent fertility indicators of high-fertility countries already resemble the ones from low-fertility countries: Completed fertility in Bosnia-Herzegovina for cohorts born in the early 1970s is 1.9, similar to Croatia. Childlessness in Montenegro (17 percent) is higher than anywhere else in the former Yugoslav republics, and the two-child family model is increasingly prevalent in North Macedonia (55-57 percent; only in Serbia is the proportion of women with exactly two children higher). 


\subsection{Discussion and further research}

As far as we know, this study is the first complex discussion of cohort fertility trends in former Yugoslavia. It summarises the main features of historical, political, economic, and social development in its regions during the twentieth century. It also analyses the cohort fertility developments based on available census data. The paper has its limitations in connecting these two parts in a causal way, and restricts itself to only several prominent influences on the fertility transition. Micro-data from fertility surveys might help shed more light on the subject. In our future studies, we would like to focus on more rigorous ways to determine the particular determinants of fertility decline, and female education in particular. Other socio-economic variables that could be analysed using existing census data are, for example, ethnicity and religion (even in the smaller-scale in case of Bosnia-Herzegovina), economic activity of women, urban-rural differences, and changes in marital dynamics.

\section{Acknowledgements}

This research is funded by the Centre of International Cooperation and Mobility (ICM) of the Austrian Agency for International Cooperation in Education and Research (OeAD-GmbH) under the program Scientific \& Technological Cooperation (WTZ) with Croatia 2018 (Croatian Ministry of Science and Education), project number HR 25/2018.

\section{References}

Andersson, Gunnar; Sobolev, Boris 2013: Small effects of selective migration and selective survival in retrospective studies of fertility. In: European Journal of Population 29,3: 345-354 [https://doi.org/10.1007/s10680-013-9293-6].

Balbo, Nicoletta; Billari, Francesco C.; Mills, Melinda 2013: Fertility in Advanced Societies: A Review of Research. In: European Journal of Population 29: 1-38 [https://doi. org/10.1007/s10680-012-9277-y].

Barclay, Kieron et al. 2016: Reproductive history and post-reproductive mortality: A sibling comparison analysis using Swedish register data. In: Social Science \& Medicine 155: 82-92 [https://doi.org/10.1016/j.socscimed.2016.02.043].

Barkalov, Nicholas Boris 1999: The fertility decline in Russia, 1989-1996: A view with period parity-progression ratios. In: Genus 55,3-4: 11-60.

Becker, Gary S. 1960: An Economic Analysis of Fertility. In: Coale, Ansley J. (Ed.): Demographic and Economic Change in Developed Countries. Princeton, NJ: Princeton University Press: 209-240.

Becker, Gary S. 1991: A treatise on the family. Enlarged edition. Cambridge, MA: Harvard University Press.

Besemeres, John F. 1980: Socialist population politics: The political implications of demographic trends in the USSR and Eastern Europe. Armonk: M.E. Sharpe. 
Bolt, Jutta et al. 2018: Rebasing 'Maddison': new income comparisons and the shape of long-run economic development. Maddison Project Working paper 10 [https://www. rug.nl/ggdc/html_publications/memorandum/gd174.pdf, 10.08.2020].

Bonifazi, Corrado; Mamolo, Marija 2004: Past and current trends of Balkans migrations. In: Espace, Populations, Sociétés 3: 519-531 [https://doi.org/10.4000/eps.356].

Botev, Nikolai 1988: Features of the Fertility Decline in the Balkan Countries since the End of XIX Century. In: Études Balkaniques 24: 87-98.

Breznik, Dušan (Ed.) 1974: The Population of Yugoslavia. C.I.C.R.E.D. Series. Belgrade: Institute of Social Sciences, Demographic Research Centre.

Breznik, Dušan (Ed.) 1980: Fertility and Family Planning in Yugoslavia. Belgrade: Institute of Social Sciences, Demographic Research Centre.

Breznik, Dušan 1991: Stanovništvo Jugoslavije. Titograd: Chronos, Konzorcijum instituta društvenih nauka.

Breznik, Dušan et al. 1972: Fertilitet stanovništva u Jugoslaviji. Beograd: Institut društvenih nauka, Centar za demografska istraživanja.

Brunnbauer, Ulf 2000: From equality without democracy to democracy without equality? Women and transition in south-east Europe. In: South-East Europe Review 3: 151-168.

Caldwell, John 1976: Toward a restatement of the demographic transition theory. In: Population and Development Review 2,3-4: 321-366 [https://doi.org/10.2307/1971615].

Calic, Marie-Janine 2019: A History of Yugoslavia. Central European Studies. West Lafayette, Indiana: Purdue University Press.

Cleland, John; Wilson, Christopher 1987: Demand Theories of the Fertility Transition: An Iconoclastic View. In: Population Studies 41,1: 5-30 [https://doi.org/10.1080/00324 72031000142516].

Coale, Ansley J.; Cotts Watkins, Susan 1986: The Decline of Fertility in Europe: The revised proceedings of a conference on the Princeton European Population Project. Princeton, NJ: Princeton University Press.

Dobrotić, Ivana 2018: Ambivalent character of leave policies development in Croatia: between pronatalist and gender equality agenda. In: Revista del Ministerio de Empleo y Seguridad Social, Special issue on leave policy and use in Mediterranean and South American countries 36: 109-128.

Drezgić, Rada 2008: Od planiranja porodice do populacione politike - promena vladajuće paradigme u srpskoj demografiji krajem 20. veka. In: Filozofija i društvo 19,3: 181-215 [https://doi.org/10.2298/FID0803181D].

Drezgić, Rada 2010: Policies and practices of fertility control under the state socialism. In: The History of the Family 15,2: 191-205 [https://doi.org/10.1016/j.hisfam.2009.11.001].

Easterlin, Richard 1975: An Economic Framework for Fertility Analysis. In: Studies in Family Planning 6.3: 54-63.

Erlich, Vera 1966: Family in Transition: A Study of 300 Yugoslav Villages. Princeton, NJ: Princeton University Press.

Eurostat Database 2019 [https://ec.europa.eu/eurostat/data/database, 1.9.2019].

Frejka, Tomas 2008: Parity distribution and completed family size in Europe: Incipient decline of the two-child family model. In: Demographic Research 19,14: 47-72 [https:// doi.org/10.4054/DemRes.2008.19.4]. 
Frejka, Tomas; Gietel-Basten, Stuart 2016: Fertility and family policies in Central and Eastern Europe after 1990. In: Comparative Population Studies 41,1: 3-56 [https://doi. org/10.12765/CPoS-2016-03en].

Frejka, Tomas; Sardon, Jean Paul 2006: Childbearing trends and prospects in low-fertility countries: A cohort analysis. European Studies of Population 13. Dordrecht/Boston/ London: Kluwer Academic Publishers [https://doi.org/10.1007/s10680-005-0693-0].

Gaćeša, Ljubica 1991: Period and cohort approach to fertility analysis of the female population of SFR of Yugoslavia in the period 1950-1987. Belgrade: Federal Bureau of Statistics.

Gelo, Jakov 1987: Demografske promjene u Hrvatskoj od 1780. do 1981. Zagreb: Globus.

Gligorov, Vladimir 2016: Elusive Development in the Balkans: Research Findings. WIIW Policy Notes and Reports 17. The Vienna Institute for International Economic Studies.

Hammel, Eugene A. 1975: Reflections on the zadruga. In: Ethnologia Slavica 7: 141-151.

Horvat, Branko 1971: Yugoslav Economic Policy in the Post-War Period: Problems, Ideas, Institutional Developments. In: American Economic Review: Supplement, Surveys of National Economic Policy Issues and Policy Research 61,3: 71-169.

Human Fertility Collection 2019: Max Planck Institute for Demographic Research (Germany) and Vienna Institute of Demography (Austria) [www.fertilitydata.org, 16.12.2019].

Hurt, Lisa S.; Ronsmans, Carine; Thomas, Suzanne L. 2006: The effect of number of births on women's mortality: Systematic review of the evidence for women who have completed their childbearing. In: Population Studies 60,1: 55-71 [https://doi. org/10.1080/00324720500436011].

Jancar-Webster, Barbara W. 1990: Women and revolution in Yugoslavia, 1941-1945. Denver, CO: Arden.

Kapor-Stanulović, Nila; David, Henry P. 1999: Former Yugoslavia and Successor States. In: David, Henry P. (Ed.): From Abortion to Contraception: Resources to Public Policies and Reproductive Behavior in Central and Eastern Europe from 1917 to the Present. Westport, CT: Greenwood Press: 279-315.

Kirk, Dudley 1996: Demographic transition theory. In: Population Studies 50,3: 361-387 [https://doi.org/10.1080/0032472031000149536].

Kohler, Hans-Peter; Billari, Francesco C.; Ortega, José Antonio 2002: The emergence of lowest-low fertility in Europe during the 1990s. In: Population and Development Review 28,4: 641-680 [https://doi.org/10.1111/j.1728-4457.2002.00641.x]

Leasure, J. William 1992: The historical decline of fertility in Eastern Europe. In: European Journal of Population 8,1: 47-75.

Lesthaeghe, Ron 1995: The second demographic transition in Western countries: an interpretation. In: Mason, Karen O.; Jensen, An-Magritt (Eds.): Gender and family change in industrialized countries. Oxford: Clarendon Press: 17-62.

Lerch, Mathias 2018: Fertility and union formation during crisis and societal consolidation in the Western Balkans. In: Population Studies 72,2: 217-234 [https://doi.org/10.1 080/00324728.2017.1412492]

Massey, Garth; Hahn, Karen; Sekulic, Dusko 1995: Women, Men, and the "Second Shift" in Socialist Yugoslavia. In: Gender and Society 9,3: 359-379 [https://doi.org/10.1177/0 89124395009003006].

Mežnarić, Silva 1985: Theory and Reality: The Status of Employed Women in Yugoslavia. In: Wolchik, Sharon L.; Meyer, Alfred G. (Eds.): Women, State and Party in Eastern Europe. Durham, NC: Duke University Press. 
Rašević, Miroslav 1971: Determinante fertiliteta stanovništva u Jugoslaviji. Beograd: Institut društvenih nauka, Centar za demografska istraživanja.

Reeves, Joy B. 1990: Social Change in Yugoslavia and Its Impact on Women. In: International Journal of Sociology of the Family 20: 125-138.

Simeunović, Vladimir 1964: Stanovništvo Jugoslavije i socijalističkih republika od 1921 1961. Beograd: Savezni zavod za statistiku.

Sklar, June L. 1974: The Role of Marriage Behavior in the Demographic Transition: The Case of Eastern Europe around 1900. In: Population Studies 28,2: 231-247.

Sobotka, Tomáš 2011: Fertility in Central and Eastern Europe after 1989: collapse and gradual recovery. In: Historical Social Research 36,2: 246-296 [https://doi.org/10.12759/ hsr.36.2011.2.246-296].

Sobotka, Tomáš; Beaujouan, Éva 2014: Two is best? The persistence of a two-child family ideal in Europe. In: Population and Development Review 40,3: 391-419. [https://doi. org/10.1111/j.1728-4457.2014.00691.x].

Somerville, Rose M. 1965: The Family in Yugoslavia. In: Journal of Marriage and Family 27,3: 350-362.

Springer, Beverly 1986: Yugoslav Women. In: Iglitzin, Lynne; Ross, Ruth (Eds.): Women in the World. Second Revised Edition. Santa Barbara, California: ABC-Clio Inc: 415438.

Surkyn, Johan; Lesthaeghe, Ron 2004: Value orientations and the second demographic transition (SDT) in Northern, Western and Southern Europe: An update. In: Demographic Research Special Collection 3: 45-86 [https://doi.org/10.4054/DemRes.2004. S3.3].

United Nations 1983: Manual X: Indirect techniques for demographic estimation. United Nations.

TransMonEE Database 2019: UNICEF Regional Office for CEE/CIS (released in June 2019) [http://transmonee.org/database, 01.09.2019].

Van Bavel, Jan 2014: The mid-twentieth century Baby Boom and the changing educational gradient in Belgian cohort fertility. In: Demographic Research 30,33: 925-962 [https://doi.org/10.4054/DemRes.2014.30.33].

van de Kaa, Dirk J. 1987: Europe's second demographic transition. In: Population Bulletin 42.1. Washington DC: Population Reference Bureau.

WIC 2014: European Demographic Datasheet 2014. Wittgenstein Centre for Demography and Global Human Capital, Vienna [www.populationeurope.org, 16.12.2019].

Woodward, Susan L. 1985: The rights of women: Ideology, policy, and social change in Yugoslavia. In: Wolchik, Sharon L.; Meyer, Alfred G. (Eds.): Women, state, and party in Eastern Europe. Durham: Duke University Press: 234-256.

Woodward, Susan L. 1995: Socialist Unemployment: The Political Economy of Yugoslavia 1945-1990. Princeton, NJ: Princeton University Press.

Zeman, Kryštof et al. 2018: Cohort fertility decline in low fertility countries: Decomposition using parity progression ratios. In: Demographic Research 38,25: 651-690 [https://doi.org/10.4054/DemRes.2018.38.25]. 
Ivan Čipin ( $\varangle$ ), Petra Međimurec. Department of Demography, Faculty of Economics and Business, University of Zagreb. Zagreb, Croatia.

E-mail: icipin@efzg.hr, pmedimurec@efzg.hr

URL: http://www.efzg.unizg.hr/icipin www.efzg.unizg.hr/pmedjimurec

Kryštof Zeman. Wittgenstein Centre for Demography and Global Human Capital, Vienna Institute of Demography/Austrian Academy of Sciences. Vienna, Austria.

E-mail: krystof.zeman@oeaw.ac.at

UR: http://www.wittgensteincentre.org/en/staff/member/zeman.htm 


\section{Appendix: Method of decomposition}

The decomposition of differences between completed cohort fertility rates of the low fertility cluster versus the high fertility cluster into the contribution of differences in parity progression rates uses the modified method used by Zeman and colleagues (2018). This method builds upon Barkalov (1999: 52-53 formulae [3-6]) and follows the sequential nature of childbearing as a chain of transitions across parities, starting from the transition to first birth and then proceeding to subsequent parity transitions. In this framework, the change in the progression rate to a given parity $i$ affects not only the number of women in this parity, but also all higher parities. The modification consists of two parts: first, we do not decompose differences in time, but between regions (clusters); and second, we decompose until higher parities (with $6+$ as the highest parity).

We first define completed cohort fertility $C F R$ in a given cluster $c$ as a function of parity progression ratios $P P R$ :

$$
\begin{aligned}
C F R^{c}= & f\left(P P R_{i-1, i}^{c}\right)=P P R_{0,1}^{c}+P P R_{0,1}^{c} * P P R_{1,2}^{c}+P P R_{0,1}^{c} * P P R_{1,2}^{c} * P P R_{2,3}^{c}+ \\
& +P P R_{0,1}^{c} * P P R_{1,2}^{c} * P P R_{2,3}^{c} * P P R_{3,4}^{c}+P P R_{0,1}^{c} * P P R_{1,2}^{c} * P P R_{2,3}^{c} * P P R_{3,4}^{c} * P P R_{4,5}^{c}+ \\
& +P P R_{0,1}^{c} * P P R_{1,2}^{c} * P P R_{2,3}^{c} * P P R_{3,4}^{c} * P P R_{4,5}^{c} * P P R_{5,6+}^{c} /\left(1-P P R_{5,6+}^{c}\right) .
\end{aligned}
$$

The difference between CFR in initial cluster 1 and cluster 2 is expressed as:

$$
d C F R^{c 1, c 2}=C F R^{c 2}-C F R^{c 1}=\sum_{j=1}^{i} d P P R_{i-1, i}^{c 1, c 2}
$$

where

$$
\begin{gathered}
F R\left(P P R_{0,1}^{c 2}, P P R_{1,2}^{c 1}, P P R_{2,3}^{c 1}, P P R_{3,4}^{c 1}, P P R_{4,5}^{c 1}, P P R_{5+, 6+}^{c 1}\right)- \\
\quad-C F R\left(P P R_{0,1}^{c 1}, P P R_{1,2}^{c 1}, P P R_{2,3}^{c 1}, P P R_{3,4}^{c 1}, P P R_{4,5}^{c 1}, P P R_{5+, 6+}^{c 1}\right) \\
d P P R_{1,2}^{c 1, c 2}=C F R\left(P P R_{0,1}^{c 2}, P P R_{1,2}^{c 2}, P P R_{2,3}^{c 1}, P P R_{3,4}^{c 1}, P P R_{4,5}^{c 1}, P P R_{5+, 6+}^{c 1}\right)- \\
\quad-C F R\left(P P R_{0,1}^{c 1}, P P R_{1,2}^{c 1}, P P R_{2,3}^{c 1}, P P R_{3,4}^{c 1}, P P R_{4,5}^{c 1}, P P R_{5+, 6+}^{c 1}\right) \\
d P P R_{2,3}^{c 1, c 2}=C F R\left(P P R_{0,1}^{c 2}, P P R_{1,2}^{c 2}, P P R_{2,3}^{c 2}, P P R_{3,4}^{c 1}, P P R_{4,5}^{c 1}, P P R_{5+, 6+}^{c 1}\right)- \\
-C F R\left(P P R_{0,1}^{c 2}, P P R_{1,2}^{c 2}, P P R_{2,3}^{c 1}, P P R_{3,4}^{c 1}, P P R_{4,5}^{c 1}, P P R_{5+, 6+}^{c 1}\right) \\
d P P R_{3,4}^{c 1, c 2}=C F R\left(P P R_{0,1}^{c 2}, P P R_{1,2}^{c 2}, P P R_{2,3}^{c 2}, P P R_{3,4}^{c 2}, P P R_{4,5}^{c 1}, P P R_{5+, 6+}^{c 1}\right)- \\
-C F R\left(P P R_{0,1}^{c 2}, P P R_{1,2}^{c 2}, P P R_{2,3}^{c 2}, P P R_{3,4}^{c 1}, P P R_{4,5}^{c 1}, P P R_{5+, 6+}^{c 1}\right) \\
d P P R_{4,5}^{c 1, c 2}=C F R\left(P P R_{0,1}^{c 2}, P P R_{1,2}^{c 2}, P P R_{2,3}^{c 2}, P P R_{3,4}^{c 2}, P P R_{4,5}^{c 2}, P P R_{5+, 6+}^{c 1}\right)- \\
-C F R\left(P P R_{0,1}^{c 2}, P P R_{1,2}^{c 2}, P P R_{2,3}^{c 2}, P P R_{3,4}^{c 2}, P P R_{4,5}^{c 1}, P P R_{5+, 6+}^{c 1}\right) \\
d P P R_{5,+6+}^{c 1, c 2}=C F R\left(P P R_{0,1}^{c 2}, P P R_{1,2}^{c 2}, P P R_{2,3}^{c 2}, P P R_{3,4}^{c 2}, P P R_{4,5}^{c 2}, P P R_{5+, 6+}^{c 2}\right)- \\
-C F R\left(P P R_{0,1}^{c 2}, P P R_{1,2}^{c 2}, P P R_{2,3}^{c 2}, P P R_{3,4}^{c 2}, P P R_{4,5}^{c 2}, P P R_{5+, 6+}^{c 1}\right)
\end{gathered}
$$




\section{Comparative Population Studies}

WWW.comparativepopulationstudies.de

ISSN: 1869-8980 (Print) - 1869-8999 (Internet)

\section{Published by}

Prof. Dr. Norbert F. Schneider

Federal Institute for Population Research D-65180 Wiesbaden / Germany

\section{(cc) BY-SA}

2020

\section{Managing Editor}

Prof. Dr. Johannes Huinink

Dr. Katrin Schiefer

\section{Editorial Assistant}

Beatriz Feiler-Fuchs

Wiebke Hamann

\section{Layout}

Beatriz Feiler-Fuchs

E-mail:cpos@bib.bund.de

\section{Scientific Advisory Board}

Karsten Hank (Cologne)

Michaela Kreyenfeld (Berlin)

Marc Luy (Vienna)

Natalie Nitsche (Rostock)

Zsolt Spéder (Budapest)

Rainer Wehrhahn (Kiel)

\section{Board of Reviewers}

Bruno Arpino (Barcelona)

Kieron Barclay (Rostock)

Laura Bernardi (Lausanne)

Gabriele Doblhammer (Rostock)

Anette Eva Fasang (Berlin)

Michael Feldhaus (Oldenburg)

Tomas Frejka (Sanibel)

Alexia Fürnkranz-Prskawetz (Vienna)

Birgit Glorius (Chemnitz)

Fanny Janssen (Groningen)

Frank Kalter (Mannheim)

Stefanie Kley (Hamburg)

Bernhard Köppen (Koblenz)

Anne-Kristin Kuhnt (Duisburg)

Hill Kulu (St Andrews)

Nadja Milewski (Rostock)

Roland Rau (Rostock)

Thorsten Schneider (Leipzig)

Tomas Sobotka (Vienna)

Jeroen J. A. Spijker (Barcelona)

Heike Trappe (Rostock)

Helga de Valk (The Hague)

Sergi Vidal (Barcelona)

Michael Wagner (Cologne) 